\title{
Genesis of iron and manganese sediments in Zoloushka Cave (Ukraine/Moldova) as revealed by $\delta^{13} \mathrm{C}$ organic carbon
}

\author{
Piotr Kotula ${ }^{1 *}$, Viacheslav Andreychouk ${ }^{2}$, Jacek Pawlyta ${ }^{3}$, Leszek Marynowski ${ }^{1}$, \\ and Izabela Jendrzejewska ${ }^{4}$ \\ ${ }^{1}$ Faculty of Earth Science, University of Silesia, Będzińska 60, 41-200 Sosnowiec, Poland \\ ${ }^{2}$ Faculty of Geography and Regional Studies, University of Warsaw, Krakowskie Przedmiescie 30, 00-927 Warsaw, Poland \\ ${ }^{3}$ Institute of Physics - CSE, Silesian University of Technology, Konarskiego 22B, 44-100 Gliwice, Poland \\ ${ }^{4}$ Institute of Chemistry, University of Silesia, Szkolna 9, 40-006 Katowice, Poland
}

\begin{abstract}
Zoloushka Cave is one of the largest maze gypsum caves in the world. Mining of the gypsum bedrock and lowering of the water level due to the pumping of groundwater led to exposure of the cave passages to vadose conditions and changed the hydrochemistry of the karst water. As a result, large quantities of $\mathrm{Fe}$ and $\mathrm{Mn}$ hydroxides were deposited in the passages. It was found that at least two groups of various organisms were involved in depositing ferrous and manganese sediments. In order to establish the mechanism of deposition, we conducted chemical analyses of the sediments and isotopic analyses of organic carbon. This enabled us to formulate a hypothetical model of the biogenic deposition of $\mathrm{Fe}$ and $\mathrm{Mn}$ compounds. According to the model, autotrophic iron bacteria precipitated Fe hydroxides. Organisms of this type assimilate $\mathrm{CO}_{2}$ from cave atmospheres and, as a result of isotopic fractionation during that process, organic matter in ${ }^{13} \mathrm{C}$ is depleted by $7.3 \%$ relative to $\mathrm{CO}_{2}$. Heterotrophic bacteria (responsible for depositing manganese oxides) parasitise on autotrophic bacteria without changing the carbon isotope composition of organic matter. Fungal organisms living in ferrous sediments separate carbon from organic matter, resulting in enrichment with the heavier carbon isotope by $2 \%$.
\end{abstract}

Keywords: gypsum karst, iron and manganese sediments, biogeochemical sediments, isotopic fractionation, carbon isotopes

Received 11 February 2019; Revised 28 August 2019; Accepted 28 August 2019

Citation: Kotula P., Andreychouk V., Pawlyta J., Marynowski L. and Jendrzejewska I., 2019. Genesis of iron and manganese sediments in Zoloushka Cave (Ukraine/Moldova) as revealed by $\delta^{13} \mathrm{C}$ organic carbon, 48 (3), 221-235. Tampa, FL (USA) ISSN 0392-6672

https://doi.org/10.5038/1827-806X.48.3.2255

\section{INTRODUCTION}

Iron and manganese are relatively common in cave environments (Hill \& Forti, 1986). Their presence is usually indicated by characteristic colours, including reddish, orange, and yellow in the case of iron, and dark-brown to black, blackish, tarry, or soot-like in the case of manganese. $\mathrm{Fe}$ and $\mathrm{Mn}$ compounds in caves are frequently accompanied by various types of cave sediments, but often form pure types of cave deposits (speleothems) (see e.g., Naum \& Butnaru, 1967; Looney, 1969; Hill \& Hill, 1971; Urbani, 1976; Foster et al., 1977; Martini \& Kavalieris, 1978; Martini, 1980; Onac et al., 1997; Provencio \& Polyak, 2001; Gázquez et al., 2011, 2012; Miller et al., 2012; Carbone et al., 2016). Host rock, which contains iron and manganese or material of various lithologies from the surroundings, transported into caves by water, is the main source of these elements in karst. Metals 'released' into caves from bedrock or allochthonous sediments usually appear as oxides or/ and hydroxides, forming more or less stable mineral phases (crystalline or amorphous) (Hill \& Forti, 1986). The mineralogy of $\mathrm{Fe}-\mathrm{Mn}$ compounds in caves depends mainly on the lithology of the bedrock (carbonates, sulphates, salts, silicates, magmatic material, and others) and the microclimatic conditions of the cave environment (especially humidity), which govern the hydration or dehydration of compounds. The widest variety of $\mathrm{Fe}$ and $\mathrm{Mn}$ compounds can be observed in caves developed in carbonate rocks - limestones, dolomites, ankerites, and siderites (see e.g., Osborne, 1978; Zimák et al., 2000; Bosák et al, 2002; Cílek et al., 2002) - because these rocks and their weathering products are usually enriched in minerals containing $\mathrm{Fe}$ and $\mathrm{Mn}$, such as pyrite, hematite, rhodochrosite, 
marcasite, limonite, and goethite (Northup et al., 2000, 2003; Boston et al., 2006). Iron often constitutes a significant part of the insoluble residuum of limestone. Hence, fissures and caverns in karstified limestones are frequently filled with the red mass of iron oxides. For this reason, as is known, soils formed on limestone under certain (Mediterranean) climatic conditions exhibit a characteristic red colour (terra rossa).

In caves developed in other types of karstified rocks, such as gypsum or salt, Fe and Mn compounds are generally allochthonous materials, mainly due to the low level of the contents of such elements in gypsum or halite. Nevertheless, in some special cases, iron and manganese sediments may appear in gypsum caves in situ due to chemical (biochemical) deposition from water solutions.

It is widely known that $\mathrm{Fe}$ and $\mathrm{Mn}$ compounds are extremely sensitive to changes in $\mathrm{pH}$ and $\mathrm{Eh}$ of water environments and oxidise when geochemical conditions change from anaerobic to aerobic, resulting in precipitation of minerals (Skinner \& Fitzpatrick, 1992). For example, in a case where an aquifer is isolated from the surface by impermeable layers (artesian, hypogenic conditions, etc.), it may be opened hydraulically and exposed to the effect of oxygen. The opening of such an aquifer (due to natural, i.e., erosion, or anthropogenic processes) is usually accompanied by radical changes in the hydrogeochemical environment, e.g., from reducing to oxidising conditions. Of course, deposition of $\mathrm{Fe}$ and Mn compounds occurs not only in karst formations but also in any other similar violation of the regime of underground water circulation accompanied by changes in hydrogeochemical conditions; as such, it is quite common (Płochniewski \& Pich, 1966; Kleczkowski et al., 1974; Macioszczyk, 1987). The deposition of $\mathrm{Fe}$ and $\mathrm{Mn}$ is often governed by microorganisms, primarily bacteria, which mediate metabolically in the processes of the mobilisation of $\mathrm{Fe}$ and $\mathrm{Mn}$ from sediments as well as in their oxidation and deposition (see e.g., Skinner \& Fitzpatrick, 1992; Hose et al., 2000; Sommers et al., 2002; Northup et al., 2003; Spilde et al., 2005; Boston et al., 2006, 2009).

Geochemical events of this kind provoked by mining activity, specifically the opening of a karst aquifer by work at a quarry, occurred in the Zoloushka Cave area, Ukraine/Moldova (Andreychouk, 2007). The history of this area represents a perfect example of hydrogeochemical changes in a cave water environment resulting in the biochemical deposition of a large quantity of iron and manganese compounds (Andreychouk \& Klimchouk, 2001; Andreychouk, 2007). The question of iron and manganese sediments, which are widespread in Zoloushka and which feature a wide variety of aggregations, is, along with the problem of speleogenesis, the most challenging and interesting among the scientific problems related to the cave. A number of publications have been devoted to this aspect of the cave (Andreychouk \& Korzyk, 1984; Volkov et al., 1986, 1987; Volkov \& Andreychouk, 1986; 1987; 1988; Volkov, 1990; Andreychouk \& Klimchouk, 2001; Andreychouk,
2007). Although the principal mechanism of the formation of these compounds in the cave has been explained, many questions remain unanswered. These concern, first of all, the role of microorganisms in the precipitation of Fe-Mn hydroxides, their types, the paragenetic relationships between the various groups of microorganisms which deposited the compounds, the formation of complex stalactiteshaped and stalagmite-shaped aggregates consisting of $\mathrm{Fe}$ and $\mathrm{Mn}$ hydroxides, and others. These issues have not been clarified to date by explanations based solely on mineralogical and geochemical considerations. To resolve them, we conducted isotopic studies of carbon in Fe-Mn formations in the atmosphere of the cave. The results of these studies suggested a hypothesis combining various types of iron and manganese formations in a single genetic cycle.

\section{ZOLOUSHKA CAVE: GEOLOGY AND FERROMANGANESE HYDROXIDES}

\section{Zoloushka Cave: geological settings}

The cave is located in the southern part of Western Ukraine, where the borders of three countries, Ukraine, Moldova, and Romania, converge (Fig. 1). The cave was uncovered during a quarry mining work in 1946, but was not surveyed by speleologists until 30 years later. Over a period of approximately 50 years, the exposed cave labyrinth was continually damaged during the excavation of gypsum. During the 1980s and 90s, a well-equipped 30-metre artificial entrance to the cave was prepared, including ladders, and natural side openings in the quarry wall were covered with waste material. These activities were carried out in order to implement a protection programme for the cave, which had been proclaimed a natural monument. It is estimated that about $7 \mathrm{~km}$ of the labyrinth had been destroyed by mining work. The total length of the passages in the surveyed part of the cave is currently around $92 \mathrm{~km}$ (Andreychouk, 2007).

The quarry and the artificial entrance into the cave are located within the territory of the Republic of Moldova, very close (100-150 m) to the Ukrainian border (Chernivtsi area, North Bukovina region). The labyrinth stretches from the entrance to the NW, towards Ukraine, and $\mathrm{NE}$, towards Moldova. The

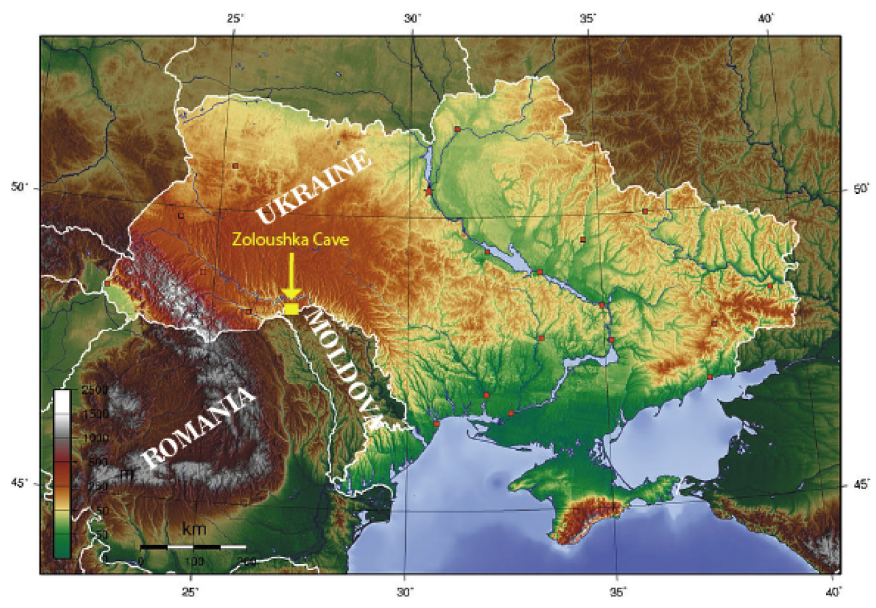

Fig. 1. Location of Zoloushka Cave in Ukraine. 
national border between Ukraine and Moldova divides the cave maze into two parts: the Ukrainian (western) and the Moldavian (eastern). The river Prut, which forms the border between Moldova and Romania, flows $1.0-1.5 \mathrm{~km}$ to the south of the quarry, separating the cave area from Romania.

The cave maze is developed in a Miocene (Upper Badenian) gypsum series 23-25 m thick. At the top, the gypsum is covered by a relatively thin $(0.5-1.4 \mathrm{~m})$ bed of well-consolidated limestone (Ratynsky Limestone) which is overlain by massive series of layered clays of the Upper Badenian (Kosowsky Formation, 10-60 $\mathrm{m}$ in thickness). Young Quaternary (QIII-QIV) alluvial (sand, gravel, loess) sediments of the III-V terraces of the Prut River lie on the eroded surface of the clays. Gypsum lies on the eroded surface of Lower Miocene limestones and marls, and, in places, on Cretaceous sandstones.

Karstified gypsum and fractured underlying rocks, as well as loose Quaternary formations, contain underground waters. Karst waters circulating in gypsum and underlying carbonate-sandstone formations are hydraulically connected, forming a joint water-bearing complex which is drained by the Prut River valley. Due to the pumping of water from the quarry, which started in the 1950s, the karst aquifer gradually declined. By the end of the 1960s, more than $80 \%$ of the gypsum series had been drained, and the cave galleries, exposed by mining activity, became accessible for speleological exploration.

The rapid changes of the hydrodynamic regime which took place after the beginning of mining work and progressive deepening of the quarry caused radical changes in the geochemical environment and the hydrogeochemistry of karst water. Geological exploratory research carried out prior to mining activity had shown that, prior to excavation by the quarry firm, the cave was almost completely filled with water. The aquifer water level was located only 2-3 $\mathrm{m}$ below the roof of gypsum. The karst waters, which moved very slowly towards the bottom of the Prut River are characterised by a high concentration of $\mathrm{H}_{2} \mathrm{~S}$ (above $100 \mathrm{mg} / \mathrm{l}$ ) and a relatively high value of TDS (3.0-4.5 g/1) (Andreychouk, 2007).

From the moment of exploitation and pumping out of the water, the quarry became an artificial drainage base for the underground water. A depression cone developed around the quarry. As a result of the activation of water circulation, the TDS content in water decreased to a level of 1.9-2.6 g/1, and degassing occurred.

The stagnating underground water regime (until the opening of the aquifer by the quarry firm) and the presence of $\mathrm{H}_{2} \mathrm{~S}$ in the water clearly proved the reducing geochemical character of the water environment and its neutral or slightly acidic $\mathrm{pH}$, which favoured the occurrence of $\mathrm{Fe}$ and $\mathrm{Mn}$ in dissolved form. Numerous search boreholes which reached the gypsum layer immediately prior to the excavation and gradual lowering of the water level (at the initial stage of operation) enabled oxygen to access the underground waters and provoked their degassing from $\mathrm{H}_{2} \mathrm{~S}$ and $\mathrm{CO}_{2}$. These events initiated a series of changes in the aquifer, causing the stage transformation of its geochemical conditions according to the following schema: reducing $\rightarrow$ transition/gley $\rightarrow$ transition/ oxidising $\rightarrow$ oxidising (Volkov, 1990; Andreychouk \& Klimchouk, 2001; Andreychouk, 2007). The change in the conditions of the aqueous environment from reducing to oxidising resulted in the deposition of $\mathrm{Fe}$ and Mn compounds.

From a morphologic perspective, Zoloushka Cave represents a cave maze consisting of passages of various sizes forming relatively separate networks (cave parts) characterised by different densities (Fig. 2). Morphological and morphometric variations in the cave network are caused mainly by structural predispositions. The largest passages and corridors are located in the upper part of the gypsum layer, where passages $1.0-6.0 \mathrm{~m}$ wide and 1.0-7.0 $\mathrm{m}$ high, characterised by oval, rhombic, or semi-spherical cross sections, predominate (Fig. 3).

The weak intensity of the exchange of the cave air with the atmosphere outside generally results in a stagnating regime of air circulation in most of the cave, resulting in the accumulation of significant amounts $0.5-4.5 \%$ of carbon dioxide $\left(\mathrm{CO}_{2}\right)$.The high content of carbon dioxide in the air is a particular feature of the cave's microclimate. We suppose that such a high concentration is a result of the poor exchange of cave air with the outside environment as well as of biogeochemical processes occurring in the cave (Andreychouk, 2007; Andreychouk et al., 2011).

As for the main types of the sediments present in the cave, the most widespread are thinly- redeposited layered clays which cover the bottoms of the galleries and the lower parts of the walls, with thicknesses ranging from several centimetres to $5-6 \mathrm{~m}$. They represent the deposits created as a result of the sedimentation of fine suspended matter in the aquatic environment. This matter occasionally appeared in
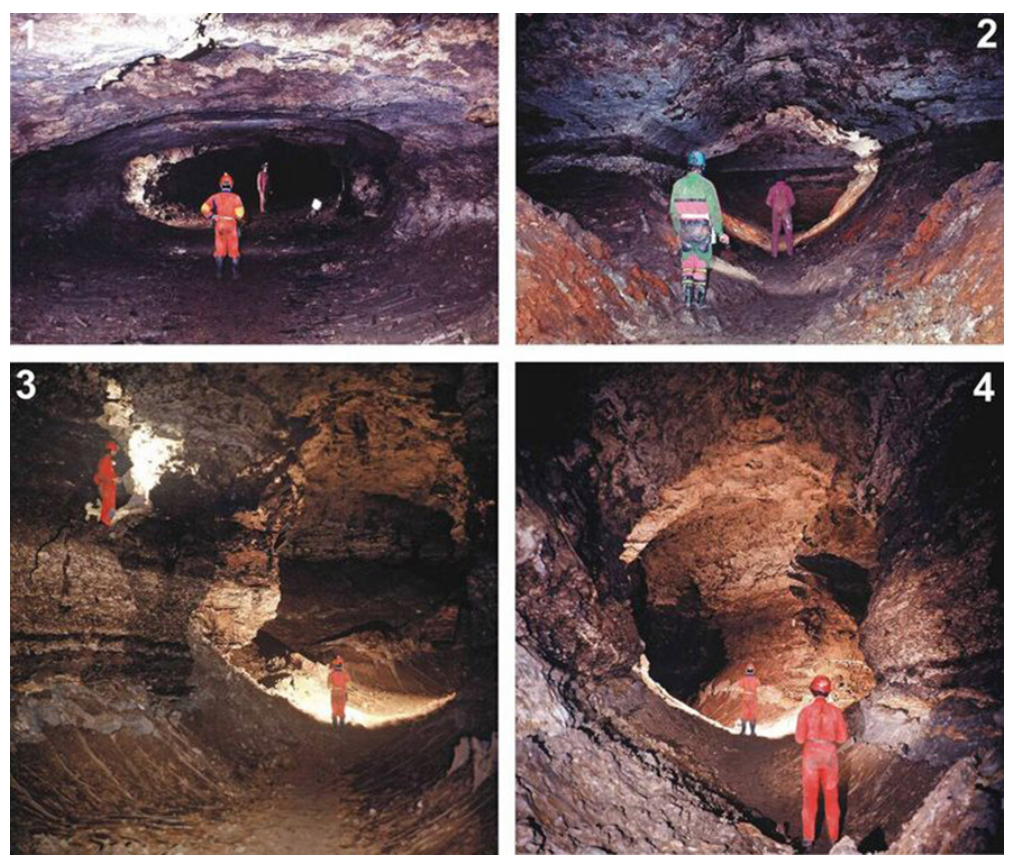

Fig. 2. Some typical passage morphologies in Zoloushka Cave. Photographs 1 and 2 by $\mathrm{V}$. Andreychouk, 3 and 4 by V. Kiselov. 


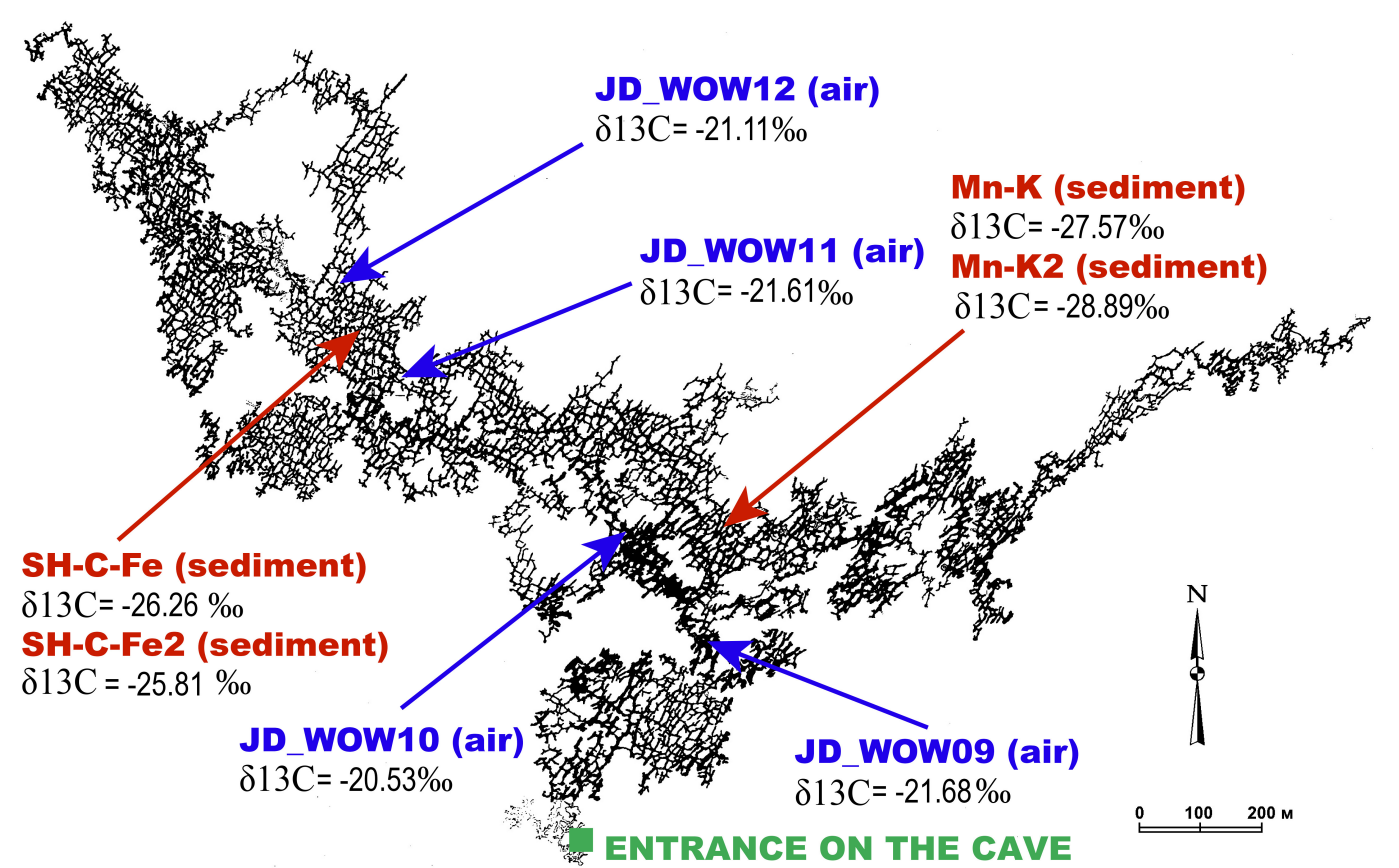

Fig. 3. Map of Zoloushka Cave showing the location of sampling points for sediments and air and the results of $\delta^{13} \mathrm{C}$ analysis in \%o VPDB.

water during the collapse of the gallery ceiling along with the Miocene clays, as well as, in some cases, alluvial deposits and soil lying above it. A relatively large quantity of organic material reached the cave, along with both the clays and, particularly, the Quaternary sediments (including the soil).

\section{Fe-Mn formations in the cave}

The deposition of iron and manganese compounds from the oxidising water was one of the results of the geochemical transformation of the water environment. Red, yellow, and black are typical of the colouration of the cave landscape of Zoloushka.

The first specialised (mineralogical and geochemical) investigations of these sediments were performed in 1985-87. These studies enabled the determination of the mineralogical phases and the chemical and elemental composition of iron and manganese formations, as well as an explanation for the regularity of their prevalence in the cave (Andreychouk \& Korzyk, 1984; Volkov \& Andreychouk, 1986, 1987; Volkov et al., 1986, 1987.

Several years later, specialised geomicrobiological tests carried out in the cave showed that various bacteria occurred in profusion on the surface of all of its environments, including such groups as sulphate reducers (Desulfovibrio desulfuricans), denitrifiers (Pseudomonas denitrificans), hydrogen producers (Clostridium spp., Acidithiobacillus ferrooxidans, Thiobacillus thioparus, T. denitrificans), methane producers, iron bacteria, and unidentified funguslike microorganisms (Volkov, 1990; Andreychouk \& Klimchouk, 2001; Andreychouk, 2007). Fe and Mn formations, especially, were exceptionally rich in bacterial life, indicating the potentially important role of microorganisms in the deposition of $\mathrm{Fe}$ and $\mathrm{Mn}$ compounds.

Further research, carried out in the 1990s, led to a more detailed explanation of the possible role of particular groups of bacteria in the geochemical evolution of the karstic aquifer; thus an essential model of the formation of Fe-Mn deposits in the cave was proposed (Andreychouk \& Klimchouk, 2001; Andreychouk, 2007). At the same time, iron deposits were covered with fungus-like microorganisms which formed colonies and gave iron deposits their bizarre shapes (hollow tubes, stalagmite-like, stalactite-like, nest-like forms, etc.). Detailed SEM investigations helped to determine the structure and composition of these fungus-like organisms, but, unfortunately, they could not be identified. According to the opinions of some geomicrobiologists, most likely they are not known to science. The results of a pilot study of these microorganisms were published in a comprehensive article (Andreychouk et al., 2009).

The above-mentioned studies showed that bacteria played an important role in the deposition of $\mathrm{Fe}$ and Mn compounds. The latter were deposited as a result of the active mediation of microorganisms in creating the conditions lowering karst water levels and oxidising cave waters. However, in the case of colonial forms of Fe-compound formation, the decisive role was played by the unidentified fungus-like microorganisms.

In order to enhance understanding of the mechanism (and relevant peculiarities) of the biogeochemical deposition of Fe and Mn compounds by chemosynthetic microorganisms in Zoloushka Cave, we investigated the organic matter and examined the isotopic state of carbon in all of the above-mentioned formations and in the air of the cave.

\section{METHODS}

Samples of iron and manganese material were collected aseptically in sterile plastic bags of various sizes at specific locations of the cave (where they appeared in the greatest amounts - Fig. 3). The collected materials were then prepared for further laboratory analysis. 


\section{Total carbon and total inorganic carbon analyses}

Amounts of total carbon (TC), total sulphur (TS), and total inorganic carbon (TIC) were determined at the Faculty of Earth Sciences, University of Silesia, Poland, using an Eltra CS-500 IR Analyser with a TIC module. Total organic carbon (TOC) was calculated as the difference between total carbon and total inorganic carbon. TC, TS, and TIC contents were measured using an infrared cell detector for the detection of $\mathrm{CO}_{2}$. For TC and TS, the gas was evolved via combustion in an oxygen atmosphere. For TIC, $\mathrm{CO}_{2}$ was obtained via a reaction with $20 \%$ hydrochloric acid. The calibration was performed in accordance with Eltra standards. Calcium carbonate content was calculated as $\mathrm{CaCO}_{3}=$ $8.333 \times$ TIC, under the assumption that all carbonate was present as calcite (Racka et al., 2010). The Eltra standards was measured prior to analysis; analytical precision and accuracy were better than $\pm 3 \%$.

\section{Isotopic investigations}

The isotopic composition of carbon stable isotopes was investigated in the organic fraction extracted from the collected samples and from cave-air carbon dioxide. Inorganic carbon (carbonate ions) was removed by using hydrochloric acid. Two different sample pretreatment methods were tested in this work.

The first was a slightly modified method described by Panno et al. (2004). The samples, designated Mn-K (Mn compound) and $\mathrm{SH}-\mathrm{C}-\mathrm{Fe}$ (Fe compound), were treated with $2 \mathrm{~N} \mathrm{HCl}$ at $60^{\circ} \mathrm{C}$ for 24 hours. Subsequently, the solution was left at room temperature to allow the sample to decant. The sedimented sample was washed with deionised water and, after 24 or 48 hours, the solution was decanted again. This step was repeated until a neutral $\mathrm{pH}$ was obtained. Finally, the samples were centrifuged and dried overnight in an oven at $45^{\circ} \mathrm{C}$. The entire process lasted over a week.

In the case of two other samples, the second method was used. The samples, designated $\mathrm{SH}-\mathrm{C}-\mathrm{Fe}-2$ and $\mathrm{Mn}-\mathrm{K}-2$, were treated with $0.5 \mathrm{~N} \mathrm{HCl}$ at $75^{\circ} \mathrm{C}$ for 3 hours. Subsequently, they were centrifuged and the solution was decanted. The sedimented sample was treated with deionised water and centrifuged, and the water was decanted until a neutral $\mathrm{pH}$ was obtained. As in the first method, finally samples were centrifuged and dried for $24 \mathrm{~h}$ in an oven at $45^{\circ} \mathrm{C}$. The entire process lasted less than 48 hours.

Cave atmosphere gas samples were collected into 5-litre PET bottles. Carbon dioxide was cryogenically separated from the cave-air gas mixture. Each gas sample was slowly pumped through a dry-ice/ alcohol-cooled water trap and two liquid-nitrogencooled carbon dioxide traps.

The stable isotopic composition of carbon was determined at the Department of Radioisotopes, Institute of Physics, CSE, Silesian University of Technology, Gliwice, Poland. The measurements were made using an IsoPrime isotope ratio mass spectrometer, produced by GV Instruments, UK, which operated in continuous flow mode with helium carrier gas. The mass spectrometer interfaced via an open splitter with an EA3000 Elemental Analyser produced by EuroVector, Italy. Several hundred micrograms of the sample material were wrapped in tin foil and subjected to combustion in excess oxygen. The working temperature of the combustion furnace of the elemental analyser was set at $1020^{\circ} \mathrm{C}$. However, due to the additional heat produced by the oxidation of the tin foil, the final combustion temperature was much higher. The resulting gases were then carried through a copper-filled reduction furnace and water trap. Finally, the remaining gases were separated using a chromatographic column and transported into the ion source of the isotopic ratio mass spectrometer.

Where the size of the samples permitted, measurements were made in triplicate. For each dozen subsamples, two different standard samples with known isotopic compositions were measured; the first was the international standard, the second the internal laboratory standard. The one-point calibration method was used for the calculation of $\delta^{13} \mathrm{C}$ values. All results were expressed in \%o VPDB. The laboratory standard FLCELAC (Boettger et al., 2007) was used for the calibration, and an IAEA-C3 sample was used as a reference for the calculations.

In the case of cave $\mathrm{CO}_{2}$ gas samples, a special apparatus was used to collect the desired amount of $\mathrm{CO}_{2}$. The gas was sampled using $100-\mu \mathrm{L}$ gas-tight syringes. The gas from the syringes was injected directly into the helium flow of the continuousflow open-split interface of the isotope ratio mass spectrometer. All gas sample measurements were made in duplicate. The IAEA-C3 sample, combusted offline and treated similarly to $\mathrm{CO}_{2}$ extracted from cave-air samples, was used as a reference. In the case of the injected samples, the one-point calibration method was used for the calculation of the $\delta^{13} \mathrm{C}$ value as well. Typical reproducibility based on repeated standards measurements for both organic and gaseous samples measurements was better than $0.20 \%$.

\section{SCANNING ELECTRON MICROSCOPY}

The images were taken in the Scanning Microscopy Laboratory, Faculty of Earth Sciences, University of Silesia, using a Philips XL30 ESEM instrument with an EDAX Sapphire analyser, coupled with an energydispersive spectrometer (ESEM-EDS). The images were acquired in high-vacuum mode using an SE detector (secondary electrons) at an accelerating voltage (V ACC) of $15 \mathrm{keV}$. Qualitative EDS microanalyses of the chemical composition of the samples were conducted at selected points of the analysed surface, chosen on the basis of the BSE (backscattered electron) images. The tested samples had previously been dried at room temperature, mounted on aluminium stubs with double-sided adhesive carbon tape, and coated with thin carbon film.

\section{Chemical analysis (ICP-OES)}

The samples were dissolved in an acid solution consisting of $\mathrm{HCl}+\mathrm{HNO}_{3}$ (in a molar ratio of 3:1). The solution was then diluted and subjected to chemical analysis. A spectroflame atomic emission spectrometer, ICP Model M (Spectro Analytical Instruments, Germany) was used for the determination 
of P, Si, Fe, Mn, Ni, Sr, Zn, Al, Ba, Ca, Co, $\mathrm{Cu}$, and $\mathrm{Mg}$. The sequential spectrometer was used with the following parameters: frequency, 27.02 $\mathrm{MHz}$; power, $1.1 \mathrm{~kW}$; demountable quartz torch, $\mathrm{Ar} / \mathrm{Ar} / \mathrm{Ar}$;

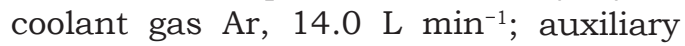

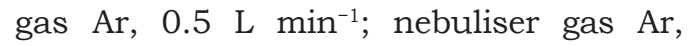

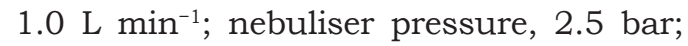
glass spray chamber according to Scott, sample flow rate, $1.0 \mathrm{~mL} \mathrm{~min}^{-1}$; wavelength range of monochromator, 165-460 nm. Wavelengths: for P, $177.5 \mathrm{~nm}$; Si, 251.6 $\mathrm{nm} ; \mathrm{Fe}, 238.2 \mathrm{~nm} ; \mathrm{Mn}, 294.2 \mathrm{~nm} ; \mathrm{Ni}$, $221.6 \mathrm{~nm}$; Sr, $216.6 \mathrm{~nm}$; Zn, $202.6 \mathrm{~nm} ; \mathrm{Al}$, $167.1 \mathrm{~nm}$; Ba, $230.4 \mathrm{~nm}$; Ca, $422.6 \mathrm{~nm}$; Co, $228.6 \mathrm{~nm}$; Cu, $324.7 \mathrm{~nm}$; Mg, 279.1

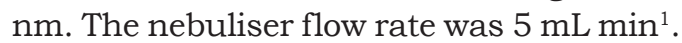
The loss on ignition (LOI) was measured after roasting in a furnace at $120^{\circ} \mathrm{C}$ for 24 hours.

\section{RESULTS}

\section{Types and distribution of Fe-Mn formations within the cave}

$\mathrm{Fe}$ and $\mathrm{Mn}$ compounds (hydroxides and oxides) occur in the cave in the following forms: films, layers, powder coatings, reniform and stalactiteand stalagmite-shaped aggregates (Figs. 4-7). Films (0.1-1.0 mm) of iron (orange and yellow, Fig. 4-1) and manganese (black, Fig. 5-1) compounds are the most common, colouring the base of the walls and the bottom of the galleries black and red and creating a characteristic colour scheme in the underground landscape of Zoloushka Cave.

In some places in the cave, $\mathrm{Fe}$ compounds form layers with thicknesses ranging from $0.5-2.0$ to $10-$ $20 \mathrm{~cm}$ or more (Fig. 4-2, 4-3). The areas of these layered formations tend to be small, i.e., $1-5 \mathrm{~m}^{2}$. Due to natural dehydration, they become loose and break up into bedded fragments and poorly cemented crusts (Fig. 4-4). They are also subject to colour changes: bright-red formations become reddish, and, when taken outside of the cave, turn red-brown and yellow, as hydroxides are transformed into oxides.

The distribution of $\mathrm{Mn}$ compounds in the cave is also characterised by significant variety (Fig. 5). In addition to films (Fig. 5-1), layers of black powder $(0.5-5.0 \mathrm{~cm})$ and accumulations of black material very similar to soot, up to 10$20 \mathrm{~cm}$ (and in one case as much as $45 \mathrm{~cm}$ ) in thickness, occur. These accumulations, which possess a secondary (re-deposited) character associated with fluctuations in karst water levels, are usually concentrated within a small area (up to $1-2 \mathrm{~m}^{2}$ ).

Hemispherical, kidney-shaped, and racemose aggregates (Fig. 5-3) covering the lower parts of the walls constitute a very peculiar type of manganese formation in the cave. In some cases, they take the form of stalactites up to $50 \mathrm{~cm}$ in length (Fig. 5-4). These stalactite-shaped aggregates are very fragile and friable. Closer inspection reveals that they are formed of very small crystals (plates) 'glued' to each other in the deposits form of arborescent aggregates with downward-oriented tops.

Analysis of the spatial relationships of $\mathrm{Fe}$ and $\mathrm{Mn}$ compounds showed (Fig. 6) that most often they occur together (Fig. 6-1), creating a specific zonality in their distribution, whereby manganese formations are usually located above ferruginous (Fig. 6-2). In separate occurrences, $\mathrm{Fe}$ compounds form mainly films, Mn compounds thin layers and accumulations of black powder (Fig. 6-3, 6-4).

The degree of the transformation of iron and manganese compounds increases in regular fashion from the deeper parts of the cave to the entrance. Near the entrance of the cave, which is subject to the
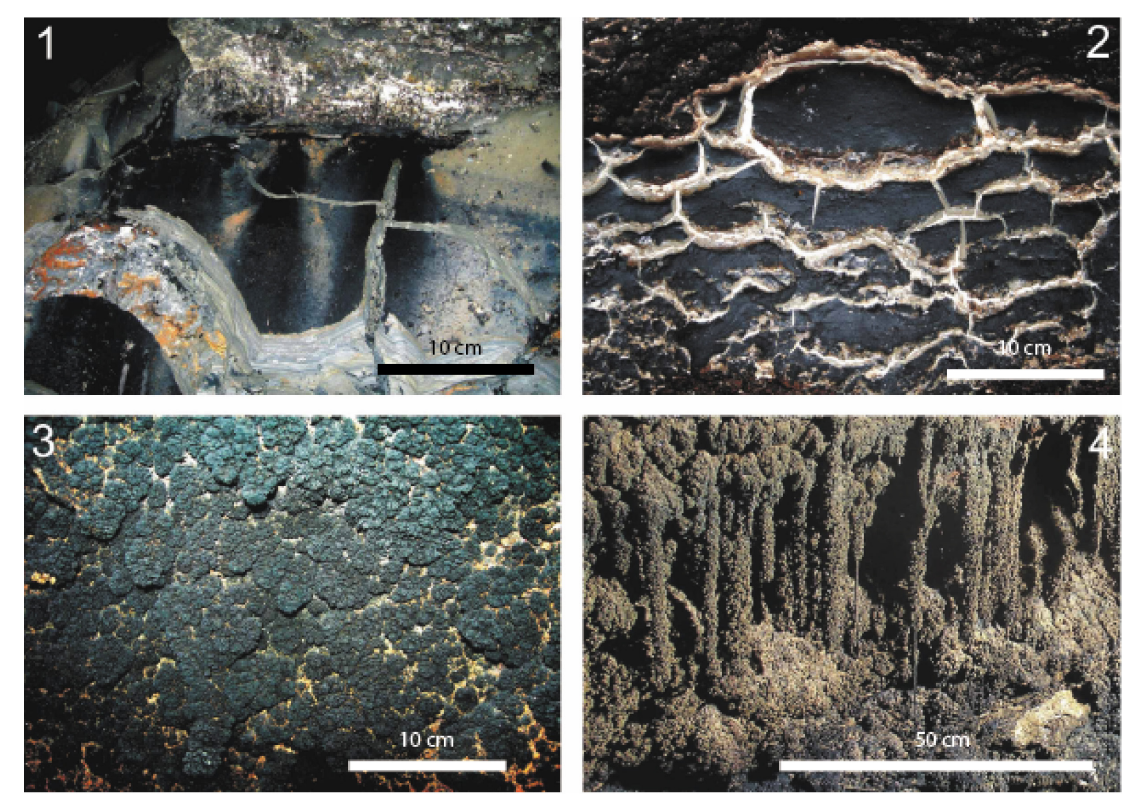

Fig. 5. Some examples of Mn compound aggregates occurring in Zoloushka Cave: 1) film on the surface of clay sediments; 2$)$ thin $(0.1-0.5 \mathrm{~cm})$ layer covering the gypsum wall; 3 ) racemose, kidney-shaped aggregates on the wall; 4) stalactite-shaped formations in a niche. Photographs by V. Andreychouk. 

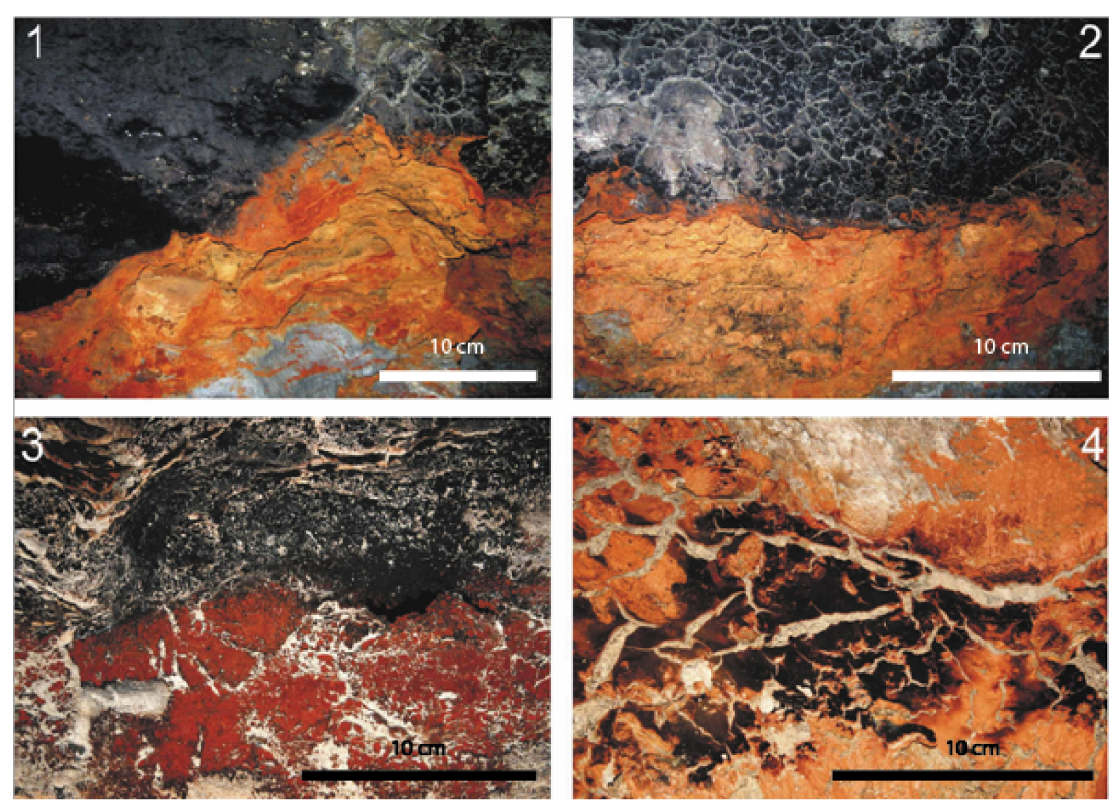

Fig. 6. Some examples of the co-occurrence of $\mathrm{Fe}$ and $\mathrm{Mn}$ compounds in various microenvironments of Zoloushka Cave: 1 and 2) Fe and Mn compounds on the walls; 3) Mn compounds on the wall and Fe compounds under the wall; 4) Mn compound powder on the film of Fe compounds covering clay sediments. Photographs by V. Andreychouk. of the surfaces of manganese spherules can also be observed. As in ferruginous hydroxides, $\mathrm{Ni}$ and some other trace elements are almost always present in small amounts in manganese compounds (see below). Calcite (in the form of small, syngenetic, and secondary crystals) and gypsum are also present in the mass of both types of compounds.

Extremely singular types of $\mathrm{Fe}$ formations include stalagmite-shaped tubular formations at the bottom of corridors, consisting mainly of iron compounds (Fig. 9-1, 9-2) and complexly shaped hollow bodies occurring on the cave ceiling (Fig. 9-3, 9-4) (Andreychouk, 2007; Andreychouk et al., 2009). The SEM investigations revealed that the bodies of these formations are formed by fibrous and jug-shaped structures ('branches' and 'pots', respectively), as well as masses of organic material which fill them (Fig. 10). Fungus-like microorganisms influence of the external atmosphere, the compounds are dehydrated and are sometimes completely transformed into oxides, especially manganese. The ferruginous formations in this location are pale brown or yellow, the manganese dark-grey and brownish. In the remote areas of the cave, they retain, respectively, 'fresh' red and black colours (with a blue tint).

Both Fe and $\mathrm{Mn}$ compounds reveal their bacterial structure under SEM (Figs. 7, 8), as images show that the ferruginous materials consist of very small nodules, resembling peas, of various sizes (from 1-2 to 5-10 microns) (Fig. 7-2, 7-6). The spherules occur separately or form (via accretion and aggregation) aggregates consisting of dozens and sometimes hundreds of individuals. The size of individual spherules is $2-5$ microns, whereas the aggregates measure 10-50 microns and more. The spherules often cover autochthonous or foreign microcrystals (calcite and, in lesser quantities, gypsum; Fig. 7-3) contained in the mass of compounds as small inclusions. The surface of these 'peas' is rough, with micropartitions which make it 'flocculent' (Fig. 7-5, 7-6). In cross section, the nodules are characterised by a zonal-concentric structure. In addition, more complex formations often occur in Fe-compound powder, sometimes oddly branched and similar to helictites (Fig. 7-4).

Manganese compounds are also formed of spherules of different sizes with a zonalconcentric internal structure (Fig. 8-3). Manganese spherules are slightly larger and differ from ferruginous in their more complex structure and less regular shape. Their size varies within the limits of 10-30 $\mu \mathrm{m}$. In contrast to the ferruginous spherules that build $\mathrm{Fe}$ hydroxides, Mn spherules are characterised by a higher degree of accretion, and virtually always form aggregates (Fig. 8-2). With significant magnification of SEM images, the flaky nature

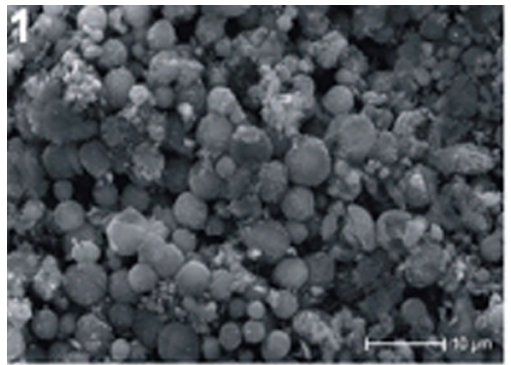
form relatively large, colonial formations, which can be attributed to microbialites, i.e., organomineral sediments formed primarily by the activity of microorganisms (see Andreychouk et al., 2009, for a detailed description on these features).

The iron microbialites of Zoloushka Cave, which are especially fungus-like, are unique in many respects and remain completely unexplored to date. However, they can be correlated with the microbialites
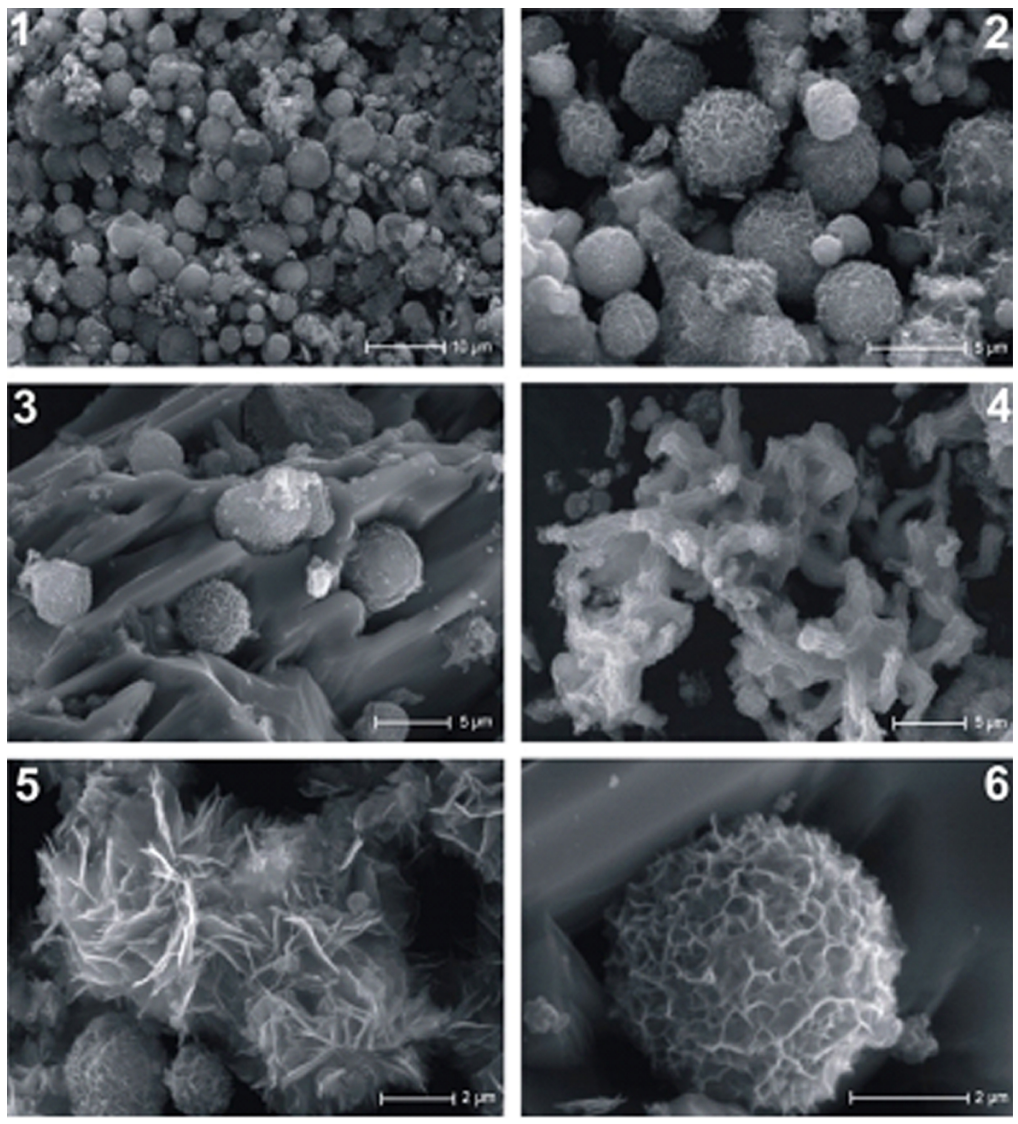

Fig. 7. SEM images of ferruginous formations: 1) general view of ferruginous sediment mass; 2) Fig. 7-1, magnified; 3) isolated iron-bacterial spherules in corrosive recesses of gypsum crystal; 4) fibrous iron-bacterial structures;

5 and 6 ) individual iron-bacterial spherules with characteristic flaky surface. 
detected in other environments rich in iron and manganese, such as the unusual flattened nodules and tube-like formations in a deep part of Connecticut Lake, New Hampshire, USA (Asikainen \& Werle, 2007), iron-manganese flattened microbialites from the shallow (1-7 m) Vermillion Lake in Minnesota, USA (Sommers et al., 2002; S. Douglas, personal communication), stalagmite-shaped formations at a depth of about 800 metres in the abandoned Soudan iron mine in Minnesota (Edwards et al., 2006; Boston \& Spilde, personal communication; C. Alexander, personal communication), and benthic carbonate stalagmite-shaped structures from Pavilion Lake in Canada (Laval et al., 2000; Lim et al., 2009; see also Fig. 11B in Carbone et al., 2016). The presence of these microbialites is explicable, given that fungal biodiversity is broad and complex (Hawksworth, 1991; Cunningham et al., 1995; Hawksworth et al., 1995).
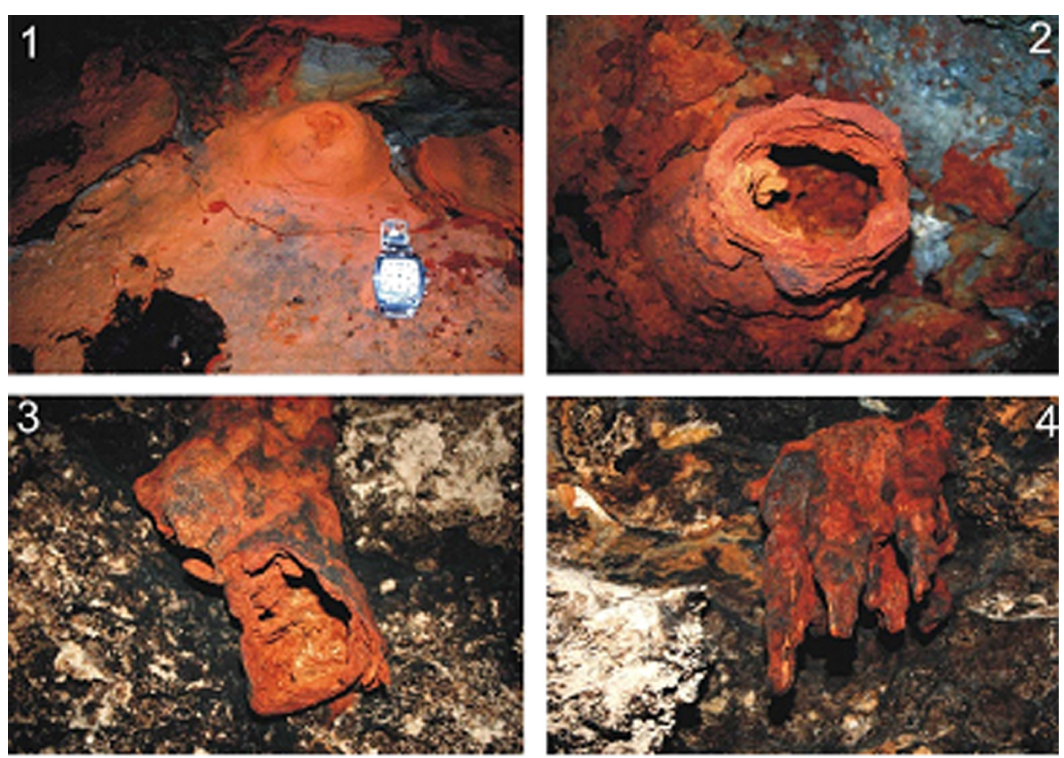

Fig. 9. Some types of ferruginous stalagmite-shaped (1), tubular (2), and stalactiteshaped $(3,4)$ formations built from unidentified fungi-like microorganisms. The height of the formations varies, with maxima of 10-15 cm (1), 35-40 cm (2), 25-30 cm (3), and 20-25 cm (4). Photographs by V. Andreychouk.

Nevertheless, some spheres, similar in appearance, have also been described in Fe-Mn compounds from deep-ocean crusts (Lusty et al., 2018).

\section{Non-organic components of Fe-Mn formations}

$\mathrm{Fe}$ and Mn compounds occur in the cave in several phases and mineral forms which are characterised by specific compositions and differ in terms of content of trace elements (Volkov et al., 1987; Volkov \& Andreychouk, 1987; Volkov, 1990). Fe compounds in a 'fresh state' (in deeper parts of the cave) occur in an amorphous phase, $\mathrm{FeOOH} \cdot \mathrm{nH}_{2} \mathrm{O}$, in which the iron content reaches 50\%. The presence of large amounts of water in compounds determines their high sorption properties (capacity to absorb microelements) and their status as oxyhydrate collectors. Fe hydroxides contain a large group of absorbed microelements, among which the
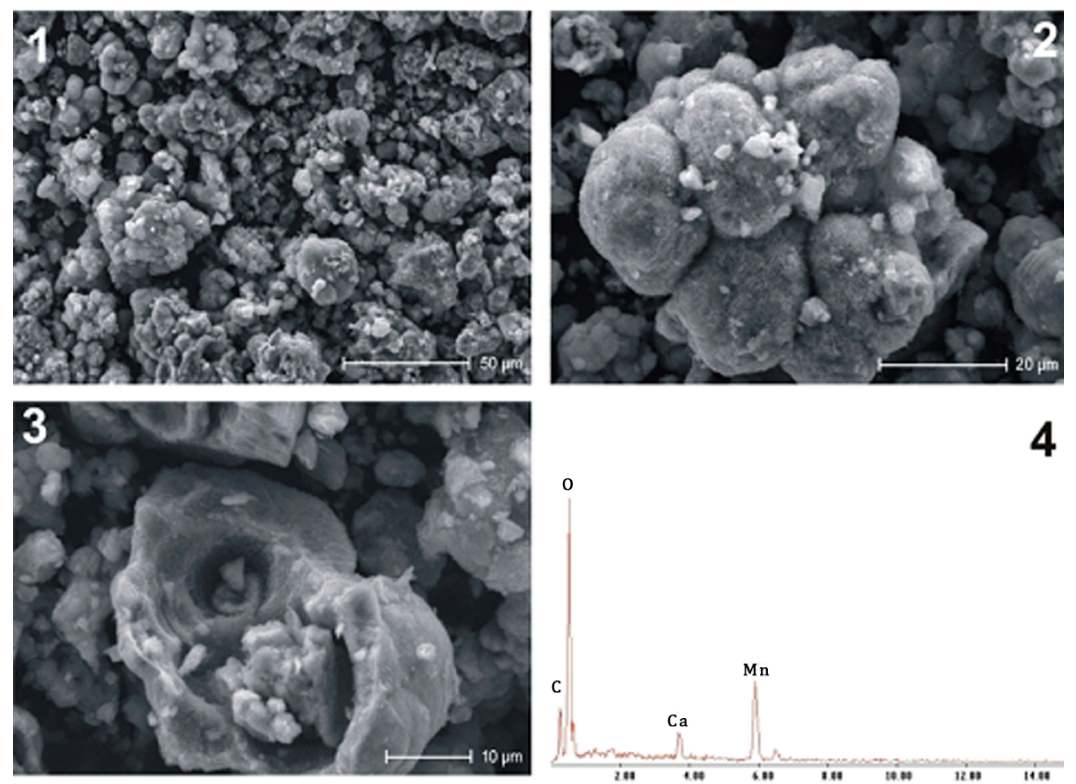

Fig. 8. SEM images of manganese formations: 1) general view of the mass of manganese compounds; 2) racemose structure of a manganese cluster: magnified Fig. $8-1$; 3) internal concentric structure of a manganese spherule; 4) qualitative EDS composition analysis of a manganese spherule. association of $\mathrm{P}, \mathrm{Cr}, \mathrm{As}, \mathrm{Be}, \mathrm{Ge}, \mathrm{Ba}, \mathrm{Pb}$, and $\mathrm{Sr}$ clearly stands out. The content of these elements is always correlated with the amount of $\mathrm{Fe}_{2} \mathrm{O}_{3}$ in the precipitate (Volkov, 1990).

Mn-compounds (oxides) are represented by two mineral species: asbolane-bouazzerite and birnessite. The formula of birnessite from Zoloushka Cave is $\mathrm{Ca}_{0.60} \mathrm{~K}_{0.07} \mathrm{Ni}_{0.08} \mathrm{Mn}^{3+}{ }_{1.43} \mathrm{Mn}^{4+}{ }_{5.57} \mathrm{O}_{14} \times 5.9 \mathrm{H}_{2} \mathrm{O}$ (Volkov et al., 1986, 1987). Asbolane-bouazzerite was identified via X-ray diffraction without the establishment of a specific formula (Volkov et al., 1986). The composition of the cave's birnessite is similar to that of deep-water oceanic formations (Chuchrov et al., 1979; 1985; Volkov \& Shterenberg, 1981). In some cases, Mn compounds occur as a mix of asbolane-bouazzerite and birnessite, in others as pure birnessite only. The main component of birnessite is $\mathrm{MnO}_{2}$, which is associated with $\mathrm{Ni}, \mathrm{Co}, \mathrm{Mo}, \mathrm{Cu}$, and $\mathrm{Zn}$.

The chemical composition of Fe-Mn sediments (Table 1) indicates that they consist mainly of iron and manganese oxides. From current and older chemical and structural studies (Volkov et al., 1987; Volkov \& Andreychouk, 1987; Volkov, 1990) it can be concluded that:

1) amorphous iron oxides are the main phase in Fe;

2) birnessite is the dominant phase in Mn sediments, while asbolane and bouazzerite have also been identified;

3) amorphous iron oxides contain a large group of absorbed microelements, among which the paragenetic association of $\mathrm{P}, \mathrm{Cr}, \mathrm{As}, \mathrm{Be}, \mathrm{Ge}, \mathrm{Ba}$, and $\mathrm{Pb}$ clearly stands out. The content of these elements is always correlated with the amount of $\mathrm{Fe}_{2} \mathrm{O}_{3}$ in the precipitate (Volkov, 1990);

4) the main component of birnessite is $\mathrm{MnO}_{2}$, which is associated with $\mathrm{Ni}, \mathrm{Co}$, $\mathrm{Mo}, \mathrm{Cu}$ and $\mathrm{Zn}$; 
5) Fe-Mn chemical sediments are clearly separated and do not mix. Mn sediments are almost devoid of iron compounds.

\section{Organic components of Fe-Mn formations}

Total organic carbon (TOC) contents in Fe and $\mathrm{Mn}$ formations from Zoloushka Cave are rather low and diverse (Table 2). The highest TOC values, in the range of 1.5 to $3.0 \%$, were obtained for the Fe sediments built from fungus-like microorganisms (PDW-KK-1 and KK samples). Fe compounds contain 1.4 to $1.5 \%$ of TOC (ST and SH-C-Fe samples), whereas formations from Mn compounds are organic-poor and characterised by TOC contents of 0.2 to $0.4 \%$ (Table 2 ).

\section{Isotopic composition of organic carbon}

According to the measured $\mathrm{CO}_{2}$ ion current recorded for Mn-rich samples in the mass spectrometer sample, the pretreatment method based on long sedimentation time resulted in a yield about six times higher than that resulting from the fast pretreatment method based on centrifugation. For Fe-rich samples, the long-time sedimentation method was only two times more effective. Comparing $\delta^{13} \mathrm{C}$ values (Table 3) for $\mathrm{Mn}$ rich samples obtained using these two pretreatment methods, we can state that there is no statistically significant difference $(\mathrm{t}$-statistic $=1.68)$ between them. A similar comparison for Fe-rich samples
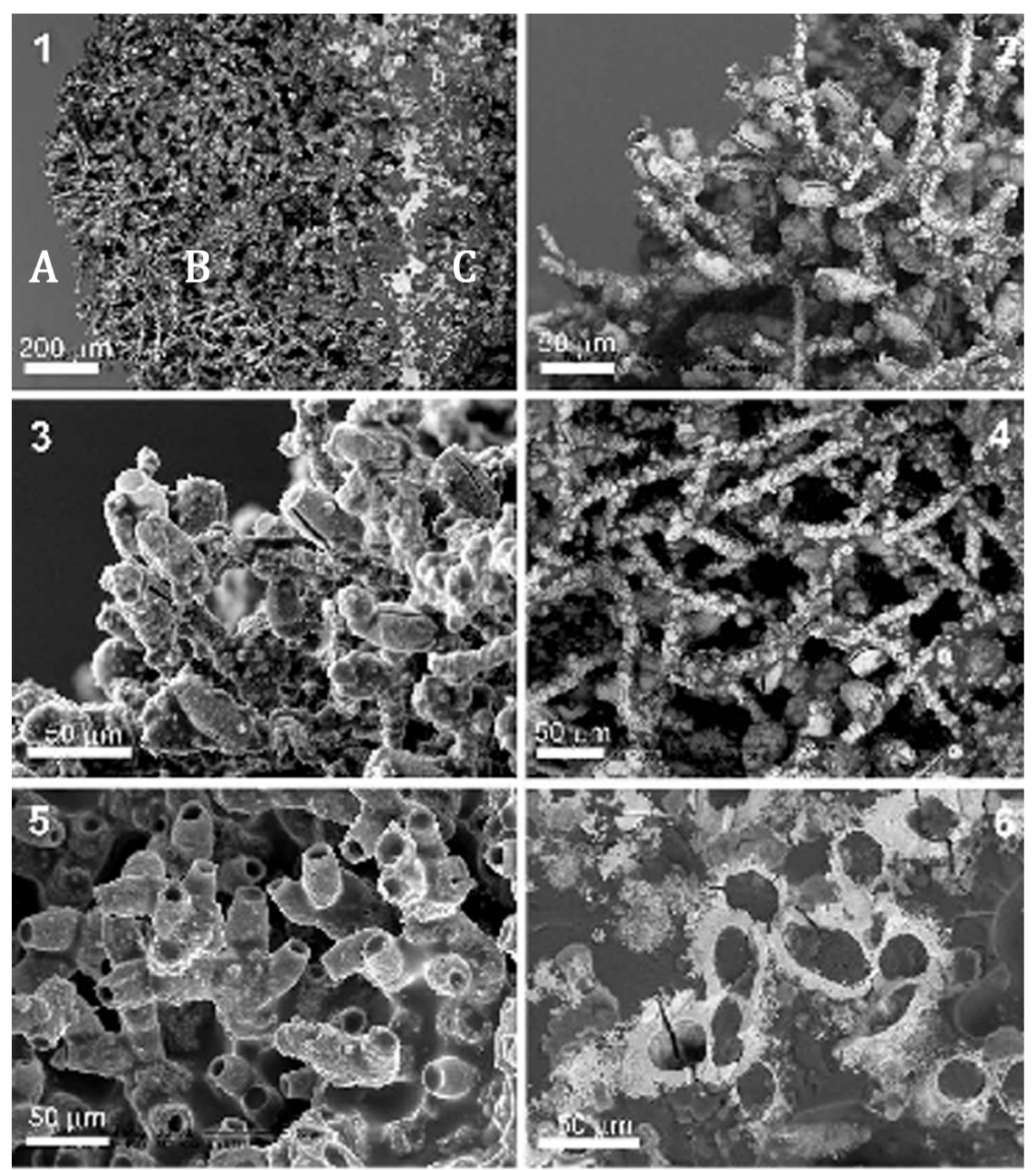

Fig. 10. Zonal structure of the wall of tubular stalagmite (in section): 1) general cross-sectional view of the wall: A) outside, B) central, C) inside; 2, 3) jug-shaped and branching formations of the outer zone; 4 ) jugs among the branched structures of the middle zone; 5) cluster of jugs in the middle zone; 6 ) jugs in organic mass of the inner zone (Andreychouk et al., 2009).
Table 1. Chemical composition of Fe-Mn formations in Zoloushka Cave (ICP-OES method).

\begin{tabular}{|l|c|c|c|c|}
\cline { 2 - 5 } \multicolumn{1}{c|}{} & \multicolumn{2}{c|}{$\begin{array}{c}\text { Fe-compounds } \\
\text { (sample name: SH-C-Fe) }\end{array}$} & \multicolumn{2}{c|}{$\begin{array}{c}\text { Mn-compounds } \\
\text { (sample name: Mn-K) }\end{array}$} \\
\hline $\mathrm{P}_{2} \mathrm{O}_{5}$ & 4.698 & \pm 0.070 & 0.4998 & \pm 0.0070 \\
\hline $\mathrm{SiO}_{2}$ & 3.356 & \pm 0.050 & 0.664 & \pm 0.010 \\
\hline $\mathrm{Fe}_{2} \mathrm{O}_{3}$ & 66.02 & \pm 0.63 & 0.1536 & \pm 0.0020 \\
\hline $\mathrm{MnO}$ & 1.192 & \pm 0.017 & 77.66 & \pm 0.16 \\
\hline $\mathrm{NiO}$ & 0.0192 & \pm 0.0010 & 0.1919 & \pm 0.0020 \\
\hline $\mathrm{SrO}$ & 0.2790 & \pm 0.0010 & 0.2765 & \pm 0.0040 \\
\hline $\mathrm{ZnO}$ & 0.0099 & \pm 0.0010 & 0.1504 & \pm 0.0020 \\
\hline $\mathrm{Al} \mathrm{O}_{3}$ & 0.1218 & \pm 0.0020 & 0.0995 & \pm 0.0010 \\
\hline $\mathrm{BaO}$ & 0.2352 & \pm 0.0030 & 0.4202 & \pm 0.0060 \\
\hline $\mathrm{CaO}$ & 9.75 & \pm 0.14 & 12.48 & \pm 0.18 \\
\hline $\mathrm{CoO}$ & 0.0060 & \pm 0.0010 & 0.0320 & \pm 0.0010 \\
\hline $\mathrm{CuO}$ & 0.0000 & \pm 0.0010 & 0.0070 & \pm 0.0010 \\
\hline $\mathrm{MgO}$ & 0.700 & \pm 0.010 & 0.934 & \pm 0.014 \\
\hline $\mathrm{LOI}$ & 8.30 & \pm 0.62 & 2.30 & \pm 0.62 \\
\hline $\mathrm{Total}$ & \multicolumn{2}{|c|}{94.6871} & \multicolumn{3}{c}{95.8689} \\
\hline
\end{tabular}

gave the same result, i.e., no statistically significant difference between $\delta^{13} \mathrm{C}$ values for the two methods $(\mathrm{t}-$ statistic $=1.98)$.

The average $\delta^{13} \mathrm{C}$ of carbon dioxide in the cave air is $-21.33 \%$ VPDB (standard deviation $\mathrm{SD}=0.54 \%$ ) $\delta^{13} \mathrm{C}$ of the organic fraction of cave Mn-rich sediments is $-28.56 \%$ VPDB (SD $=0.80 \%$ o) and $\delta^{13} \mathrm{C}$ of the Fe-rich sediments is $-26.07 \%$ VPDB $(\mathrm{SD}=0.30 \%$ ). The average content of organic carbon $\delta^{13} \mathrm{C}$ in $\mathrm{Fe}$-rich sediments differs significantly from $\delta^{13} \mathrm{C}$ contents, both in the $\mathrm{CO}_{2}$ in cave air and in $\mathrm{Mn}$ rich sediments $(\mathrm{t}$-statistic $=2.9$ for the former test).

\section{DISCUSSION}

The issues of the deposition of $\mathrm{Fe}$ and Mn compounds in the cave as a reaction to the changes in the hydrogeochemical conditions of the karst aquifer caused by the establishment of the quarry and its drying are presented in Volkov et al. (1987), Volkov (1990), Andreychouk \& Klimchouk (2001), and Andreychouk (2007). The new data presented here, primarily related to isotopes, but also including materials from our previous research, enable a discussion of the origin of the Fe-Mn sediments of the cave and answer some key questions, such as the following:

1) Was the deposition of the $\mathrm{Fe}$ and $\mathrm{Mn}$ compounds exclusively chemical in nature, or biochemical, involving activity on the part of microorganisms? If biochemical, how significant was the role of microorganisms in the deposition?

2) Why do Fe and Mn compounds occur separately in cross sections of the described layers? Moreover, 
Table 2. Organic matter content in various types of Fe-Mn formations in Zoloushka Cave.

\begin{tabular}{|c|c|c|c|c|c|c|}
\hline \multirow{2}{*}{ Samples } & \multirow{2}{*}{ Sample type } & TIC & TC & TS & TOC $=$ TC - TIC & $\mathbf{C C}$ \\
\hline & & \multicolumn{5}{|c|}{ Content \% wt. } \\
\hline KK & \multirow{4}{*}{$\begin{array}{c}\text { Fe-compounds } \\
\text { (hydroxides) }\end{array}$} & $1.100 \pm 0.022$ & $2.600 \pm 0.026$ & $0.140 \pm 0.001$ & $1.500 \pm 0.036$ & $8.900 \pm 0.178$ \\
\hline PDW-KK-1 & & $0.700 \pm 0.014$ & $3.700 \pm 0.037$ & $0.330 \pm 0.003$ & $3.000 \pm 0.072$ & $6.200 \pm 0.124$ \\
\hline SH-ST & & $0.700 \pm 0.014$ & $2.300 \pm 0.023$ & $0.140 \pm 0.001$ & $1.600 \pm 0.036$ & $6.200 \pm 0.124$ \\
\hline $\mathrm{SH}-\mathrm{C}-\mathrm{Fe}$ & & $0.7500 \pm 0.015$ & $2.200 \pm 0.022$ & $0.240 \pm 0.002$ & $1.450 \pm 0.034$ & $6.300 \pm 0.126$ \\
\hline $\mathrm{Mn}-\mathrm{K}$ & \multirow{3}{*}{$\begin{array}{l}\text { Mn-compounds } \\
\text { (oxides) }\end{array}$} & $0.0200 \pm 0.0004$ & $0.500 \pm 0.005$ & $0.0100 \pm 0.0001$ & $0.480 \pm 0.011$ & $0.200 \pm 0.004$ \\
\hline $\mathrm{Mn}-\mathrm{K}-1^{*}$ & & 0 & $0.440 \pm 0.004$ & $0.0100 \pm 0.0001$ & $0.440 \pm 0.011$ & 0 \\
\hline Mn-E & & $0.0100 \pm 0.0002$ & $0.300 \pm 0.003$ & $0.0800 \pm 0.0008$ & $0.290 \pm 0.005$ & $0.100 \pm 0.002$ \\
\hline
\end{tabular}

TIC - total inorganic carbon; TOC - total organic carbon; TC - total carbon; TS - total sulphur; CC - carbonate content;

$\mathrm{Mn}-\mathrm{K}-1^{*}$ - as sample $\mathrm{Mn}-\mathrm{K}$, but after chemical treatment to remove carbonates

Table 3. Average isotopic composition of carbon in cave air and in some types of the Fe-Mn formations in Zoloushka Cave.

\begin{tabular}{|c|c|c|c|}
\hline \multirow{2}{*}{ Sample type } & \multirow{2}{*}{ Sample } & $\delta^{13} \mathrm{C}$ & Average value \\
\hline & & (\%o VPDB) & (\%o VPDB) \\
\hline \multirow{4}{*}{ Mn-compounds } & Mn-K & -27.57 & -27.57 \\
\hline & \multirow{3}{*}{ Mn-K2 } & -29.52 & \multirow{3}{*}{-28.89} \\
\hline & & -28.64 & \\
\hline & & -28.50 & \\
\hline \multirow{5}{*}{ Fe-compounds } & \multirow{3}{*}{$\mathrm{SH}-\mathrm{C}-\mathrm{Fe}$} & $-25,99$ & \multirow{3}{*}{-26.26} \\
\hline & & -26.33 & \\
\hline & & -26.33 & \\
\hline & \multirow{2}{*}{$\mathrm{SH}-\mathrm{C}-\mathrm{Fe} 2$} & -25.70 & \multirow{2}{*}{-25.81} \\
\hline & & -25.92 & \\
\hline
\end{tabular}

why are Fe compounds positioned below Mn compounds in cases where they occur together?

3) Why do more complex morphological shapes, such as stalactite- and stalagmite-shaped aggregates, occur in addition to layers and films in locations where Fe compounds have accumulated?

A concise model of the formation and transformation of Fe and Mn hydroxides can be described as follows. It has long been known that Fe and $\mathrm{Mn}$ compounds dissolved in underground waters are sensitive to changes in the $\mathrm{pH}$ and Eh of the aquatic environment. Much attention was devoted to this issue, among others, in papers by Kleczkowski et al., 1974; Macioszczyk, 1987; and other authors. Both Fe and $\mathrm{Mn}$, in an acidic environment $(\mathrm{pH}<6)$ and in transitional and reducing hydrogeochemical conditions, reside in underground waters in a dissolved state - in ionic form (i.e., $\mathrm{Fe}^{2+}$, $\mathrm{Mn}^{2+}$ and others, depending on the composition and TDS of water), in the form of neutral and colloidal particles, in absorbed form, and in the form of more or less durable organic (in cases where the water contains a significant amounts of organic matter, e.g., fulvic and humic acids) and inorganic complexes. A change in hydrogeochemical conditions involving an increase in alkalinity and a gradual transformation from reducing into oxidating conditions leads to the precipitation of $\mathrm{Fe}$ and $\mathrm{Mn}$ compounds, usually in the form of hydroxides. In the process of the oxidation of these compounds, ferrous and manganese bacteria usually play an important role, as they benefit from the chemical energy released during the oxidation of $\mathrm{Fe}^{2+}$ to $\mathrm{Fe}^{3+}$ and of $\mathrm{Mn}^{2+}$ to $\mathrm{Mn}^{3+}$ and $\mathrm{Mn}^{4+}$. This results in the metabolic accumulation, internal or external, of significant quantities of $\mathrm{Fe}$ or $\mathrm{Mn}$ compounds (15-20\% and more; see Lukashev, 1958), which may be the source of ferromanganese and so-called cave microbialites, i.e., ferromanganese deposits (Barbić \& Savić, 1985; Ivanova, 1986; Northup et al., 2003; Spilde et al., 2005; Andreychouk et al., 2009; Carmichael et al., 2013). The optimal functional ranges for microorganisms depositing Fe and Mn compounds in hydrogeochemical conditions are, in terms of $\mathrm{pH}$, 5.5-9.5, and in terms of Eh, +50-800. The higher the redox potential, the lower the alkalinity of the solution, which is favourable for the biochemical precipitation of $\mathrm{Fe}$ and $\mathrm{Mn}$ compounds. It is generally believed that the growth of ferrous bacteria depends only slightly on the concentration of iron in water, as these bacteria can thrive at concentrations ranging from 0.02 to $10 \mathrm{mg} / \mathrm{dm}^{3}$. Very high iron concentrations $\left(>14 \mathrm{mg} / \mathrm{dm}^{3}\right)$ inhibit their development (Macioszczyk, 1987). The presence of dissolved organic matter and $\mathrm{CO}_{2}$ in water stimulate the deposition process.

Earlier geomicrobiological studies carried out in the cave in the late 1980s and early 90s clearly indicated the important role of ferrous and manganese microorganisms in the deposition of $\mathrm{Fe}$ and $\mathrm{Mn}$ compounds. Examination of these compounds via SEM enables direct observation of ferrous and manganese microorganisms (Figs. 7, 8, and 10).

The separate (unmixed) occurrence of $\mathrm{Fe}$ and $\mathrm{Mn}$ sediments in the cave indicates that the sediments were deposited by different groups of bacteria, i.e., ferrous and manganese, and not by ferro-manganese, which can deposit $\mathrm{Fe}$ and $\mathrm{Mn}$ simultaneously (the bacteria from the Leptothrix group are characterised by such properties). The microscopic examination of both types of sediments showed morphological differences between them, as neither mutual penetration of layers nor the presence of transition zones suggesting that the sediments may be capable of mixing were detected. Moreover, the content of 
organic carbon in the manganese sediments, lower than that of the ferrous deposits, may suggest that the manganese compounds were formed at a later stage. The occurrence of Mn sediments on Fe sediments in the cave also indicates their separate genesis in terms of depositing microorganisms.

In many places, more complex colonial forms unidentified fungi-like microorganisms, representing a higher level of biological organisation and a more complex metabolism - occur on ('parasitise') morphologically complex ferrous bacterial deposits.

The analysis of spatial relationships between groups of microorganisms and the sediments they formed, as observed in SEM images, showed that the process of compound deposition took place in stages, and also that genetic (evolutionary) relationships existed between particular groups. This was also indicated by isotopic studies (see below).

At this point, on the basis of the above information, we were able to state conclusively that the process of formation of $\mathrm{Fe}$ and $\mathrm{Mn}$ compounds in the cave included the significant involvement of specialised microorganisms. One possible scenario is as follows: during the long history of the cave's formation in hypogenic conditions (Andreychouk, 2007), under the relatively tight cover of clay sediments, and in the completely aquatic cave maze, hydrochemical conditions were weakly alkaline. At the final stage of the hydrogeochemical history of the cave (approximately 10,000-70 years), the waters from the aquifer in Quaternary alluvial deposits, enriched with organic matter as well as soil material rich in organic acids, entered through the chimneys, which had been flooded due to gravity, in the roof of the cave. These events gradually created conditions favourable for the reduction of sulphates (with the involvement of $D$. desulfuricans) and accumulation of $\mathrm{H}_{2} \mathrm{~S}$. The reductive activity of anaerobic microorganisms reduced the Eh of the aquatic environment, which in turn favoured the dissolution and accumulation of $\mathrm{Fe}^{2+}$ and $\mathrm{Mn}^{2+}$ in water and $\mathrm{Fe}$ sulphides in the clay sediments of the cave.

As shown by geological surveys conducted just before the karstic aquifer was opened by the quarry (in the second half of the 1940s), the karst waters were characterised at that time by a high level (4-5 $\mathrm{g} / \mathrm{dm}^{3}$ ) of mineralisation (high TDS content), as well as being enriched in $\mathrm{Fe}^{2+}$ and $\mathrm{Mn}^{2+}$, saturated with hydrogen sulphide (up to $\mathrm{mg} / \mathrm{dm}^{3}$ ), and low in oxygen (Volkov, 1990; Andreychouk \& Klimchouk, 2001; Andreychouk, 2007). These circumstances determined the significantly reducing nature of the aquatic environment, which in turn resulted in the mobilisation of $\mathrm{Fe}$ and $\mathrm{Mn}$ forms dissolved in water, primarily in the form of sulphides.

With the beginning of work on the gypsum deposit and the opening of the 'sealed' karstic aquifer through dozens of boreholes, $\mathrm{O}_{2}$ began to penetrate the cave environment. Oxygen provoked the activity of thionic bacteria, which proceeded to oxidise $\mathrm{H}_{2} \mathrm{~S}$ (Thiobacillus thioparus) and sulphur formed in the oxidation process (T. thiooxidans). The latter promoted (in the presence of sulphides, sulphur, $\mathrm{Fe}^{2+}$, and $\mathrm{Mn}^{2+}$, especially in cave clays) the activity of ferrous (such as Acidithiobacillus ferrooxidans) and manganese bacteria by producing $\mathrm{H}_{2} \mathrm{SO}_{4}$, which resulted in the accumulation of this compound in underground oxidised waters, including colloidal forms of $\mathrm{Fe}$ and $\mathrm{Mn}$. The bacterial oxidation of $\mathrm{H}_{2} \mathrm{~S}$ led to continued oxidative conditions and the stratification of the cave aquifer into two zones (without a clear border): the upper zone characterised by neutral or weakly alkaline and definitely oxidising conditions, the lower by slightly more acidic, reducing conditions. These zones corresponded to hydrogeochemical environments characterised by different conditions and by different forms of $\mathrm{Fe}$ and $\mathrm{Mn}$. In the oxidising conditions of the upper zone, Fe and Mn compounds began to precipitate, though not very actively, colouring the gypsum walls of the cave yellow and black. In the weakly acidic conditions of the lower zone, Fe and Mn were mobilised, accumulating in water in increasing amounts. As the aquifer oxidised, the upper zone ('oxidation front') gradually moved downward, 'squeezing' the lower zone with its reducing conditions and accumulated resources of dissolved $\mathrm{Fe}$ and $\mathrm{Mn}$ compounds and leaving the colourful stripes that marked the lower zone's decline on the walls. The deposition of Fe and Mn compounds within the upper zone was not very active; most likely it occurred in a purely chemical manner and involved bacteria. However, this process did not occur on a massive scale, because the main resources of iron and manganese in mobilised form were contained in the degraded lower zone.

Mass precipitation of $\mathrm{Fe}$ and Mn compounds, which left their accumulations in the form of the cave deposits, occurred at the time the quarry was established along with the initiation of water-pumping activities. The active oxidising aeration of the 'physically' open karst collector significantly accelerated the process of stratification of geochemical conditions in the water environment and the neutralisation of the environment, which led to the active precipitation of $\mathrm{Fe}$ and Mn hydroxides. During this process, freshly formed $\mathrm{Fe}$ and $\mathrm{Mn}$ hydroxides actively absorbed such elements as $\mathrm{Ni}, \mathrm{Co}, \mathrm{Cu}, \mathrm{Zn}, \mathrm{Mo}$, and others from the water, usually accompanying them and forming a paragenetic association (Volkov et al., 1985, 1987).

The mass precipitation of $\mathrm{Fe}$ and $\mathrm{Mn}$ compounds covering the bottom parts of the cave corridors undoubtedly occurred through the mediation of ferrous and manganese bacteria. The active, decisive role of microorganisms is indicated, in addition to the above-mentioned direct mechanisms (SEM images), by the enrichment of manganese formations (birnessite and asbolan-bouazzerite) with organic matter and the overfilling of $\mathrm{Fe}$ hydroxides with fungus-like organisms.

As mentioned above, the absence of any mixing of ferric and manganese masses indicates their separate deposition by geochemically specialised groups of ferruginous and manganese microorganisms. The most commonly described bacterium responsible for iron oxidation is Acidithiobacillus ferrooxidans. This type of bacteria has been identified and described in the environment of Zoloushka Cave (Andreychouk \& 
Klimchouk, 2001). A. ferrooxidans is an autotrophic organism that uses chemical energy (iron oxidation) to assimilate carbon from $\mathrm{CO}_{2}$. However, determination of the type of microorganisms responsible for the oxidation of manganese is problematic. Heterotrophic manganese-oxidising bacteria, most commonly mentioned in the literature (Maki et al., 1987; Greene \& Madgwick, 1988; Miyajima, 1992), assimilate not $\mathrm{CO}_{2}$ but simpler organic compounds, such as the remains of other organisms. The source of carbon is important due to the following considerations concerning isotopic fractionation.

Laboratory research in the field of microbiology may be helpful in specifying the mechanisms of the bacterial formation of $\mathrm{Fe}$ and $\mathrm{Mn}$ deposits. Cowie et al. (2009) examined the differences in carbon isotopic fractionation between autotrophic and heterotrophic bacteria. In laboratory conditions, autotrophic bacteria assimilated $\mathrm{CO}_{2}$ and, as a result of fractionation, produced organic matter through the depletion of carbon isotopes by $8 \%$ o compared to atmospheric $\mathrm{CO}_{2}$. Heterotrophic bacteria, parasitising on autotrophic bacteria, did not fractionate carbon in organic matter.
On the other hand, Hobbie et al. (2001) and Ruess et al. (2005), who conducted research on carbon fractionation for several types of fungi, demonstrated that fungi fractionate carbon from food only to a small extent; however, some species (Polyporus sp.) enriched organic matter by about $3.5 \%$, while one species (Cladosporium cladosporioides) was capable of depleting organic matter by about $0.7 \%$.

Having compared the average $\delta^{13} \mathrm{C}$ values of carbon dioxide in the Zoloushka cave air with $\delta^{13} \mathrm{C}$ content in organic fraction of cave Mn-rich sediments, we suggest that organic carbon in these sediments is the residue of autotrophic bacteria which assimilated carbon dioxide from the atmosphere according to the established carbon isotope fractionation scheme (Cowie et al., 2009). The average content of organic carbon $\delta^{13} \mathrm{C}$ in Fe-rich sediments differs significantly from the corresponding content in both the $\mathrm{CO}_{2}$ in cave air and Mn-rich sediments. Based on these facts and studies (Ruess et al., 2005; Cowie et al., 2009), we suggest that carbon transformation in the system 'cave air $\mathrm{CO}_{2}-\mathrm{C}$ of organic matter of $\mathrm{Fe}$ and $\mathrm{Mn}$ sediments' may appear as shown in Fig. 11.

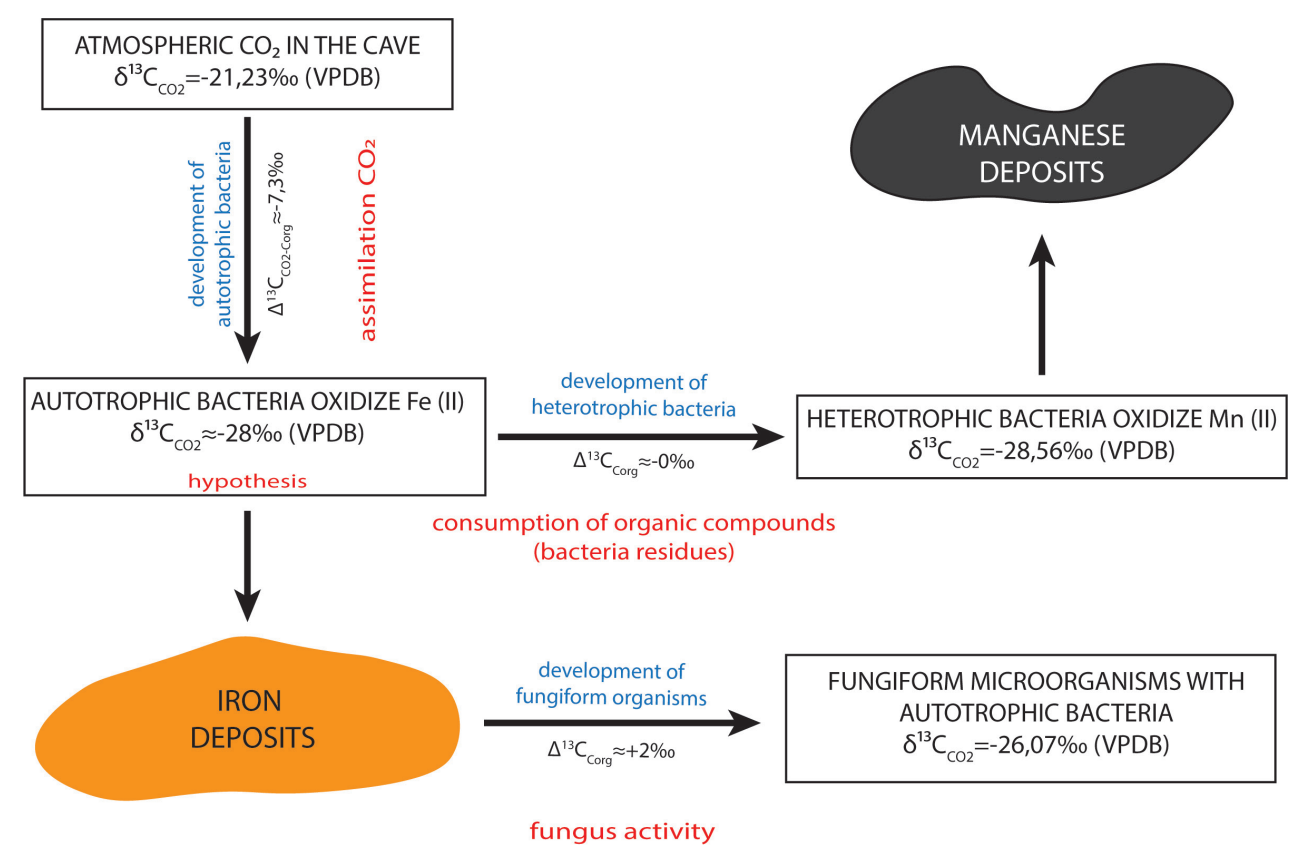

Fig. 11. Hypothetical transformation of carbon in the biogenic (bacterial) cycle of the formation of Fe and Mn compounds in Zoloushka Cave.

In the final stage of the opening of the cave maze by the quarry and radical changes in the hydrogeochemical conditions of the aquifer, autotrophic bacteria ( $A$. ferrooxidans) began assimilating carbon from the cave atmosphere, significantly enriched with $\mathrm{CO}_{2}\left(\delta^{13} \mathrm{C}\right.$ $21.23 \%$ ) , and transforming it into organic matter, with $\delta^{13} \mathrm{C}$ equal to $-28 \%\left(\Delta^{13} \mathrm{C}\right.$ is approximately $-7.3 \%$ o.). Even today, after $60-70$ years of the cave's exposure to the external environment, the content of $\mathrm{CO}_{2}$ in the cave air remains very high, $1-4 \%$ or more, due to its weak natural ventilation. Next, the organic residuals of the bacteria were consumed by heterotrophic organisms (bacteria oxidising $\mathrm{Mn}$ ), generally without the carbon fractionation (as in a laboratory study by Cowie et al. 2009). The organic matter of $\mathrm{Fe}$ compounds may also have served as a source of food for fungi-like microorganisms coexisting with autotrophic Fe bacteria. This transformation was accompanied by carbon isotopic fractionation $\left(\Delta^{13} \mathrm{C}\right)$ between the two organic residuals of approximately $2.0 \%$.

\section{CONCLUSIONS}

This study, including isotope studies, on the ferrous and manganese sediments of Zoloushka Cave, has enabled the formulation of the following conclusions, which answer the questions posed in the introduction of this article:

1. The remains of microorganisms (bacteria and fungus-like organisms) detected in the Fe and Mn sediments by SEM suggest quite clearly that these 
sediments were formed with the involvement of these organisms and constitute the product of their metabolic cycles. Thus, they are biogenic sediments, or so-called microbialites.

2. The separate, unmixed occurrence of ferrous and manganese formations in the cave is due to the creation of the above-mentioned types of sediments as the result of two separate biogeochemical processes. Their formation took place with the involvement of various groups of bacteria, both ferrous and manganese, as indicated by their differing chemical composition and 'physiognomy' (the structure and shapes of the organisms) visible under SEM and by the isotopic differences between them.

3. The location, characteristic of the cave, of manganese sediments on ferrous sediments is a reflection of the evolutionary-genetic relationship between them. The content of organic carbon, lower in manganese than in ferrous sediments, may suggest that manganese compounds were formed as secondary features in the presence of the originally deposited ferrous formations. Their formation may have been caused by heterotrophic bacteria consuming organic carbon collected by autotrophic ferrous bacteria in ferrous sediments.

4. Stalactite- and stalagmite-shaped colonial ferrous bodies, usually 'growing' from ferrous masses, are composed of the remains of fungus-like microorganisms that most probably functioned in a close relationship with autotrophic ferrous bacteria. This is indicated by the joint occurrence of these groups of microorganisms, their complex spatial and structural relationships (visible in SEM photographs), and the insignificant values of organic carbon fractionation in strictly bacterial carbon formations and formations built of fungus-like microorganisms.

5. The isotopic analyses of organic carbon conducted on the cave's ferrous and manganese sediments showed correlations between the isotopic biofractionation values obtained in the laboratory (data from Hobbie et al., 2001; Ruess et al., 2005; Cowie et al., 2009) and in the cave environment (our data). The values of isotope ratios of organic carbon from biogenic carbon and manganese cave deposits are useful to determine their formation sequence.

\section{ACKNOWLEDGEMENTS}

The authors would like to thank very much the reviewers of this manuscript. Their comments and suggestions have raised in significant degree a quality of the paper.

\section{REFERENCES}

Andreychouk V. \& Klimchouk A.B., 2001 - Geomicrobiology and redox geochemistry of the karstified Miocene Gypsum Aquifer, Western Ukraine: The study from Zoloushka Cave. Geomicrobiology, 18 (3): 275-295.

https://doi.org/10.1080/01490450152467796
Andreychouk V. \& Korzyk V., 1984 - Zoloushka cave system. Caves: Types and Methods of Studies, Perm, p. 25-29 (in Russian).

Andreychouk V., Klimchouk A., Boston P. \& Galuskin E., 2009 - Unique iron-manganese colonies of microorganisms in Zoloushka Cave (Ukraine-Moldova). Speleology and Karstology, 3: 5-25 (in Russian).

Andreychouk V., Teleshman I. \& Kouprich P., 2011 - Spatial-dynamic peculiarities of carbon dioxide distribution in the air of Zoloushka Cave. Speleology and Karstology, 7: 15-25 (in Russian).

Andreychouk V., 2007 - Zoloushka Cave. Faculty of Earth Sciences, Silesian University (Poland) and Ukrainian Institute of Speleology and Karstology, Ukrainian Academy of Sciences, Sosnowiec-Symferopol, 408 p. (in Russian).

Asikainen C.A. \& Werle S.F., 2007 - Accretion of ferromanganese nodules that form pavement in Second Connecticut Lake, New Hampshire. Proceedings of the National Academy of Sciences of the United States of America, 104 (45): 17579-17581.

https://doi.org/10.1073/pnas.0708132104

Barbić F. \& Savic I., 1985 - To know the population of $\mathrm{Fe}-\mathrm{Mn}$ bacteria and their ecology in the underground waters of Serbia (Yugoslavia). Glasnik Prirody Museum Beograd, 40: 5-16 (in Serbian-Croatian).

Boettger T., Haupt M., Knöller K., Weise S.M., Waterhouse J.S., Rinne K.T., Loader N.J., Sonninen E., Jungner H., Masson-Delmotte V., Stievenard M., Guillemin M-T., Pierre M., Pazdur A., Leuenberger M., Filot M., Saurer M., Reynolds C.E., Helle G. \& Schleser G.H., 2007 - Wood cellulose preparation methods and mass spectrometric analyses of $\delta^{13} \mathrm{C}, \delta^{18} \mathrm{O}$, and nonexchangeable $\delta^{2} \mathrm{H}$ values in cellulose, sugar, and starch: An interlaboratory comparison. Analytical Chemistry, 79: 4603-4612. https://doi.org/10.1021/ac0700023

Bosák P., Bella P., Cilék V., Ford D., Hercman H., Kadlec J., Osborne A. \& Pruner P., 2002 - Ochtiná aragonite cave (western Carpathians, Slovakia): morphology, mineralogy of the fill and genesis. Geologica Carpathica, 53 (6): 399-410.

Boston P.J., Hose L.D., Northup D.E. \& Spilde M.N., 2006 - The microbial communities of sulfur caves: A newly appreciated geologically driven system on Earth and potential model for Mars. Karst Geomorphology, Hydrology, \& Geochemistry Geological Society of America, Special Paper, 404: 331-344. https://doi.org/10.1130/2006.2404(28)

Boston P.J., Spilde M.N., Northup D.E., Curry M.C., Melim L.A. \& Rosales-Lagarde L., 2009 - Microorganisms as speleogenetic agents: Geochemical diversity but geomicrobial unity. Hypogene Speleogenesis and Karst Hydrology of Artesian Basins. Ukrainian Institute Speleology \& Karstology. Special Paper, 1: 51-57.

Carbone C., Dinelli E. \& De Waele J., 2016. Characterization of minothems at Libiola (NW Italy): morphological, mineralogical, and geochemical study. International Journal of Speleology, 45 (2): 171-183. https://doi.org/10.5038/1827-806X.45.2.1944

Carmichael M.J., Carmichael S.K., Santelli C.M., Strom A. \& Bräuer S.L., 2013 - Mn(II)-oxidizing bacteria are abundant and environmentally relevant members of ferromanganese deposits in caves of the Upper Tennessee River Basin. Geomicrobiology Journal, 30 (9): $779-800$.

https://doi.org/10.1080/01490451.2013.769651

Chuchrov F., Gorshkov A., Sivcov A. \& Berezovskaya V., 1979 - About the new mineral phases of oceanic manganic microconcretions. Izwestiya Academii Nauk SSSR, Geologia, 1: 83-95 (in Russian). 
Chuhrov F., Saharov B., Gorshkov A., Dric V. \& Dikov Y., 1985 - Struktura bernessita iz Tichogo Okeana (Structure of birnessite from Pacific). Izwestiya Academii Nauk SSSR, Geologia, 8: 66-73 (in Russian).

Cilék V., Bosák H., Melka K., Žak K., Langrová A. \& Osborne A., 1998 - Mineralogické výskumy v Ochtinské Aragonitové Jeskyni. Aragonit, 3: 7-12 (in Czech).

Cowie B.R., Slater G.F., Bernier L. \& Warren L., 2009 - Carbon isotope fractionation in phospholipid fatty acid biomarkers of bacteria and fungi native to an acid mine drainage lake. Organic Geochemistry, 40 (9): 956-962.

https://doi.org/10.1016/j.orggeochem.2009.06.004

Cunningham K.I., Northup D.E., Pollastro R.M., Wright W.G. \& LaRock E.J., 1995 - Bacteria, fungi, and biokarst in Lechuguilla Cave, Carlsbad Caverns National Park, NM. Environmental Geology, 25: 2-8.

https://doi.org/10.1007/BF01061824

Edwards R.A., Rodriguez-Brito B., Wegley L., Haynes M., Breitbart M., Peterson D.M., Saar M.O., Alexander S., Alexander E.C. \& Rohwer F., 2006 - Using pyrosequencing to shed light on deep mine microbial ecology. BMC Genomics 7: 57.

https://doi.org/10.1186/1471-2164-7-57

Foster C., Martini J. \& Mignat J.P., 1977 - Jewel Cave - eastern Transvaal. South African Speleological Association Bulletin, 19: 15-17.

Gázquez F., Calaforra J.M. \& Forti P., 2011 - Black Mn$\mathrm{Fe}$ crusts as markers of abrupt palaeoenvironmental changes in El Soplao Cave (Cantabria, Spain). International Journal of Speleology, 40 (2): 163-169. https://doi.org/10.5038/1827-806X.40.2.8

Gázquez F., Calaforra J.M. \& Rull F., 2012. Boxwork and ferromanganese coatings in hypogenic caves: an example from Sima de la Higuera Cave (Murcia, SE Spain). Geomorphology, 177-178: 158-166. https://doi.org/10.1016/j.geomorph.2012.07.022

Greene A.C. \& Madgwick J.C., 1988 - Heterotrophic manganese-oxidizing bacteria from Groote Eylandt, Australia. Geomicrobiology Journal, 6: 119-127. https://doi.org/10.1080/01490458809377829

Hawksworth D.L., 1991-The fungal dimension of biodiversity: magnitude, significance, and conservation. Mycological Research, 95: 641-655. https://doi.org/10.1016/S0953-7562(09)80810-1

Hawksworth D.L., Kirk P.M., Sutton B.C. \& Pegler D.N., 1995 - Ainsworth and Bisby's dictionary of the fungi ( $8^{\text {th }}$ Ed.). CAB International, Wallingford, $616 \mathrm{p}$.

Hill C.A. \& Forti P., 1986 - Cave minerals of the world. National Speleological Society, Huntsville, Alabama, $238 \mathrm{p}$.

Hill C.A. \& Hill A.A., 1971 - Paxton's Cave. Southwestern Caver, 10 (4): 53.

Hobbie E.A., Weber N.S. \& Trappe J.M., 2001 Mycorrhizal vs saprotrophic status of fungi: the isotopic evidence. New Phytologist, 150: 601-610. https://doi.org/10.1046/j.1469-8137.2001.00134.x

Hose L.D., Palmer A.N., Palmer M.V., Northup D.E., Boston P.J. \& DuChene H.R., 2000 - Microbiology and geochemistry in a hydrogen sulphide-rich karst environment. Chemical Geology, 169: 399-423.

https://doi.org/10.1016/S0009-2541(00)00217-5

Ivanova T., 1986 - The Fe-hydroxides films as peculiar geochemical system. Earth's life, Moscow, p. 123-127 (in Russian).

Kleczkowski A., Adamczyk A. \& Witczak S., 1974 - Iron in the waters of the high terrace of the Vistula east of Cracow. Rocznik Polskiego Towarzystwa Geologicznego, XVIV (2-3): 377-410 (in Polish).
Laval B., Cady S.L., Pollack J.C., McKay C.P., Bird J.S., Grotzinger J.P., Ford D.C. \& Bohm H.R., 2000 - Modern freshwater microbialite analogues for ancient dendritic reef structures. Nature, 407: 626-629.

https://doi.org/10.1038/35036579

Lim D.S.S, Laval B.E., Slater G., Antoniades D., Forrest A.L., Pike W., Pieters R., Saffari M., Reid D., SchulzeMakuch D., Andersen D. \& McKay C.P., 2009-Limnology of Pavilion Lake B.C., Canada - Characterization of a microbialite forming environment. Fundamental and Applied Limnology, 173 (4): 329-351. https://doi.org/10.1127/1863-9135/2009/0173-0329

Looney J., 1969 - Duncan field cave system - Oklahoma's amazing maze. National Speleological Society News, 27 (7): 95-98, 104.

Lukashev K., 1958 - The bases of lithology and geochemistry of a weathering crust. Belarusian Academy of Science, Minsk, 415 p. (in Russian).

Lusty P.A., Hein J.R. \& Josso P., 2018 - Formation and occurrence of ferromanganese crusts: Earth's storehouse for critical metals. Elements, 14: 313-318.

https://doi.org/10.2138/gselements.14.5.313

Macioszczyk A., 1987. Hydrogeochemistry. Wydawnictwo Geologiczne, Warsaw, 475 p. (in Polish).

Maki J.S., Tebo B.M., Palmer F.E., Nealson K.H. \& Staley J.T., 1987 - The abundance and biological activity of manganese-oxidizing bacteria and Metallogeniumlike morphotypes in Lake Washington, USA. FEMS Microbiology Ecology, 45: 21-29.

https://doi.org/10.1111/j.1574-6968.1987.tb02334.x

Martini J. \& Kavalieris I., 1978 - Mineralogy of the Transvaal caves. Geological Society of South Africa Transactions, 81: 47-54.

Martini J., 1980 - Sveite, nuevo mineral de la cueva del cerro Autana (abs.). Boletin de la Sociedad Venezolana Geologia, 22: 1-2.

Miller A.Z., Dionísio A., Sequeira-Braga M.A., HernándezMariné M., Afonso M.J., Muralha V.S.F., Herrera L.K., Raabe J., Fernández-Cortés A., Cuezva S., Hermosin B., Sanchez-Moral S., Chaminé H. \& Saiz-Jimenez C., 2012 - Biogenic Mn oxide minerals coating in a subsurface granite environment. Chemical Geology, 222-223: 181-191.

https://doi.org/10.1016/j.chemgeo.2012.07.005

Miyajima T., 1992 - Production of metallogenium-like particles by heterotrophic manganese-oxidizing bacteria collected from a lake. Archives of Microbiology, 158: 100-106. https://doi.org/10.1007/BF00245212

Naum T. \& Butnaru E., 1967. Le volcano karst des Calimani (Carpates Roumaines). Annales de Spéléologie, 22 (4): 749-755.

Northup D.E., Barns S.M., Yu L.E., Spilde M.N., Schelble R.T., Dano K.E., Crossey L.J., Connolly C.A., Boston P.J., Natvig D.O. \& Dahm C.N., 2003 Diverse microbial communities inhabiting ferromanganese deposits in Lechuguilla and Spider Caves. Environmental Microbiology, 5: 1071-1086.

https://doi.org/10.1046/j.1462-2920.2003.00500.x

Northup D.E., Dahm C.N., Melim L.A., Spilde M.N., Crossey L.J., Lavoie K.H., Mallory L., Boston P.J., Cunningham K.I. \& Barns S.M., 2000 - Evidence for geomicrobiological interactions in Guadalupe (NM) Caves. Journal of Cave and Karst Studies, 62: 80-90.

Onac B.P., Pedersen R.B., Tysseland M., 1997 - Presence of rare-earth elements in black ferromanganese coating from Vântului cave (Romania). Journal of Cave and Karst Studies 59: 128-131.

Osborne R.A.L., 1978 - Structure, sediments and speleogenesis at Cliefden Caves, New South Wales. Helictite, 16 (1): 3-31. 
Panno S.V., Curry B.B., Wang H., Hackley K.C., Liu C-L., Lundstrom C. \& Zhou J., 2004 -Climate change in southern Illinois, USA, based on the age and $\delta^{13} \mathrm{C}$ of organic matter in cave sediments. Quaternary Research, 61 (3): 301-313. https://doi.org/10.1016/j.yqres.2004.01.003

Płochniewski Z. \& Pich J., 1966 - Fe and $M n$ in underground waters of different hydrogeochemical environments. Kwartalnik Geologiczny, 10 (3): 872-882 (in Polish).

Provencio P.P. \& Polyak V.J., 2001 - Iron oxide-rock filaments: Possible fossil bacteria in Lechuguilla Cave, New Mexico. Geomicrobiology Journal, 18 (3): 297-309. https://doi.org/10.1080/01490450152467804

Racka M., Marynowski L., Filipiak P., Sobstel M., Pisarzowska A. \& Bond D.P.G., 2010 - Anoxic Annulata Events in the Late Famennian of the Holy Cross Mountains (Southern Poland): geochemical and palaeontological record. Palaeogeography, Palaeoclimatology, Palaeoecology, 297: 549-575.

https://doi.org/10.1016/j.palaeo.2010.08.028

Ruess L., Tiunov A., Haubert D., Richnow H.H., Häggblom M.M. \& Scheu S., 2005 - Carbon stable isotope fractionation and trophic transfer of fatty acids in fungal based soil food chains. Soil Biology and Biochemistry, 37 (5): 945-953.

https://doi.org/10.1016/j.soilbio.2004.09.015

Skinner H.C.V. \& Fitzpatrick R.W., 1992 - Biomineralization processes of iron and manganese: Modern and Ancient Environments. Catena, Supplement 21, 432 p.

Sommers M.G., Dollhopf M.E. \& Douglas S., 2002: Freshwater ferromanganese stromatolites from Lake Vermilion, Minnesota: Microbial culturing and environmental scanning electron microscopy investigations. Geomicrobiology Journal, 19 (4): 407-427. https://doi.org/10.1080/01490450290098513

Spilde M.N., Northup D.E., Boston P.J., Schelble R.T., Dano K.E., Crossey L.J. \& Dahm C.N., 2005 Geomicrobiology of cave ferromanganese deposits: A field and laboratory investigation. Geomicrobiology Journal, 22 (3-4): 99-116.

https://doi.org/10.1080/01490450590945889
Urbani P., 1976 - Polish-Venezuelan expedition studies Sarisariñama caves. National Spelelological Society Bulletin, 34 (11): 194-195.

Volkov I. \& Shterenberg L., 1981 - Main types of Fe-Mn ores in contemporary reservoirs. Lithology and Deposits, 5: 4-26 (in Russian).

Volkov S., 1990 - Geochimicheskiye izmeneniya sredy pri technogennom vozdeystvii na pescheru Zolushka (Geochemical environmental changes in Zolouska Cave due to the activities of the industry). Geochimiya, 5: 741-751 (in Russian).

Volkov S. \& Andreychouk V., 1986 - About the karst type of Mn ore occurrence. The reports of $1^{\text {st }}$ conference of young scientists and specialists of IG and GGI of Ukrainian Academy of Science, 7881: 9 (in Russian).

Volkov S. \& Andreychouk V., 1987 - K woprosu o gidrogeochimiccheskojy zonalnostiv peschere Zoloushka (On the hydrogeochemical zoning Zoloushka Cave). Perm. Prakticheskoye ispolzovaniye pescher gipsovogo karsta, p. 22-23.

Volkov S. \& Andreychouk V., 1988 - Zelezo-margancevye stalagmity wv peschere Zolushka (Fe-Mn stalagmites from Zoloushka Cave). Peschery, Peschery v gipsach i angidritach, p. 128-130.

Volkov S., Andreychouk V. \& Yanchouk E.A., 1986 Nachodka birnessita $v$ gipsovoy peschere (Birnessite from gypsum caves). Peschery, 20: 113-114.

Volkov S., Andreychouk V., Yanchouk E.A. \& Smirnov B.I., 1987 - Modern ferro-manganese deposits of the Zolushka Cave. Mineralogicheskiy sbornik, 41 (1): 7983 (in Russian).

Volkov S., Smirnov B.I. \& Yanchouk E.A., 1987 - Zelezomargancevye obrazowaniya peschery Zolushka (Fe-Mn formation from Zoloushka Cave). Doklady Academii Nauk SSSR, 292 (2): 451-454 (in Russian).

Zimák J., Faimon J. \& Štelcl J., 2000 - The manganeserich coatings on the walls of the Cisarska Cave (Moravian Karst). Geologické výzkumy na Moravěa ve Slezsku v. r. 1999, p. 167-169 (in Czech). 